\title{
Changing Names with Style: Mutual Fund Name Changes and Their Effects on Fund Flows
}

\author{
MICHAEL J. COOPER, HUSEYIN GULEN, and P. RAGHAVENDRA RAU*
}

\begin{abstract}
We examine whether mutual funds change their names to take advantage of current hot investment styles, and what effects these name changes have on inflows to the funds, and to the funds' subsequent returns. We find that the year after a fund changes its name to reflect a current hot style, the fund experiences an average cumulative abnormal flow of $28 \%$, with no improvement in performance. The increase in flows is similar across funds whose holdings match the style implied by their new name and those whose holdings do not, suggesting that investors are irrationally influenced by cosmetic effects.
\end{abstract}

MUTUAL FUNDS OFFER A UNIQUE OPPORTUNITY to study the behavior of individual investors via the examination of mutual fund flow data. This is important, since investors' asset allocation decisions across mutual funds may ultimately affect asset returns. For example, Goetzmann, Massa, and Rouwenhorst (2002) document that factors extracted from the covariance matrix of mutual fund flows provide incremental information beyond broad-based asset class returns in explaining returns in the cross-section.

In this paper, we provide striking new evidence of seemingly irrational behavior by mutual fund investors when they allocate assets across mutual funds. We also provide evidence of timing behavior on the part of fund managers who appear to take advantage of the suboptimal behavior of investors. Specifically, we analyze fund flow patterns around conditional name changes in the mutual fund industry. We define conditional name changes as name changes by mutual funds either toward a name of a particular style when the corresponding style premium is up, or away from a name of a particular style when the corresponding style premium is down. We examine what effects these name changes have on the flows in and out of the funds, and the funds' subsequent returns. To

\footnotetext{
*Cooper and Rau are with the Krannert Graduate School of Management, Purdue University. Gulen is with the Pamplin College of Business, Virginia Tech. We would like to thank Sean Collins, Diane del Guercio, Dave Denis, Diane Denis, Joost Driessen, Ken French, Zoran Ivković, Ravi Jagannathan, Mike Lemmon, Tim Loughran, John McConnell, Wanda Wallace, Russ Wermers, Jeff Wurgler, and seminar participants at the College of William and Mary, the University of Arizona, the University of Utah, Virginia Tech, the Batten Conference at the College of William and Mary, the 2003 European Finance Association meetings, the University of Illinois Conference on Bear Markets, and the 2003 Western Finance Association meetings for helpful comments. We thank Don Autore and Jim Garrett for excellent research assistant work. Comments from the editor, Rick Green, and an anonymous referee are also gratefully acknowledged.
} 
summarize our results, we find that flows to funds increase dramatically when funds change their names to look more (less) like the current positive (negative) return styles. This relation holds even for the funds (which comprise a majority of the funds in our sample) whose holdings do not materially reflect the style implied by their new name.

How prevalent are such conditional mutual fund name changes? The Financial Times (see Wine and Sullivan (2001)) reports that after the end of the technology bubble in 2000, mutual fund companies changed the names of the funds under their control to reflect a "value" orientation without changing the portfolio managed by the fund. According to the paper:

The portfolios remain much the same, but the names are a changing at a rapid rate. Hundreds of U.S. mutual funds have altered their names this year to reflect the more sober mood of the markets- "New Economy" and "growth" are out, and "value" is definitely in. "Investment companies are ripping names from the headlines and slapping them on funds that haven't changed a bit," said Russ Kinnel, director of fund analysis at Morningstar, which tracks the performance of mutual funds. Funds which were last year boasting of their exposure to the high-technology sector are this year reassuring potential investors with names that suggest an ability to find "value" amid the tech wreckage.

We identify a sample of 296 equity mutual funds that make a style name change over the period April 1994 to July 2001. Funds are defined as having a style name change if the new name is different from the old name by one of the following style identifiers: "value," "growth," "small," or "large."

Name changes for these funds appear to be motivated by reductions in fund inflows prior to the name change. Relative to other funds from the universe of mutual funds, the name-change funds experience a significantly negative fund flow over the 6 months before the name change, charge lower marketing $12 \mathrm{~b}-1$ fees, earn lower Fama-French three-factor alphas prior to the name change, and tend to be older funds. When funds do change their names, the new name is likely to be either associated with the current "hot" style or away from the current "cold" style. For example, as the value or size premium increases (decreases), funds add (delete) the corresponding style identifier to (from) their names.

To examine the effects of name changes on fund flows, we use an event study framework. To create a control sample of funds used to compute "abnormal flows" to the funds in our sample, we use the relatively new and innovative methodology of "propensity score" matching (Villalonga (2004), Hillion and Vermaelen (2004)). This matching method has the advantage of allowing us to form a control group of funds that is screened along multiple dimensions, not just a few, allowing for a cleaner test of the effects of fund name changes on flows.

When funds do change their names, they earn significantly positive abnormal fund flows. Abnormal flows are on the order of $20 \%$, in the 1 year after the namechange month, for all of the funds in our sample. To put this into perspective, the average fund in our sample has total net assets (TNA) of $\$ 299$ million in the 
month before the name change. At the end of the year, the increase in TNA, in excess of the value earned by a matching mutual fund, is over $\$ 60$ million. With 296 funds in our sample, the value created by name changes is approximately $\$ 18$ billion over the 7-year period in our sample.

The increase in fund flow is entirely concentrated, however, on funds that make a hot style name change-changing toward (away from) a particular style when the corresponding style premium is up (down). These funds earn cumulative abnormal flows (CAFs) of $27.63 \%$ in the year after the name-change month, as compared to a statistically insignificant increase for funds that make cold style name changes-changing toward (away from) a particular style when the corresponding style premium is down (up).

We test whether there is a difference in flows when the name change is cosmetic in the sense that the fund's investing style, as reflected by the fund's new name, does not reflect its portfolio holdings, as opposed to noncosmetic name changes, where the style implied in the fund's new name does match the holdings of the fund. We find no difference in abnormal flows across the cosmetic and noncosmetic name-change types. After controlling for performance, size, fund age, and other characteristics, the funds that experience the greatest increase in flows are those that switch toward the current hot style (or away from the cold style) and those that spend the most money on marketing their new name.

Our results are consistent with a simple story. Older, poorer performing funds (in terms of three-factor alphas) that have not spent much on marketing fees and that have experienced a significant drop in their fund inflows change their names to earn an increased flow from being associated with the current glamour style. We find that the funds with the greatest increases in post-name-change flows are hot style funds associated with the greatest increases in marketing expenditures. However, the increased flows are not all driven by advertising; we also find large increases in flows for funds that make hot name changes and either do not increase their advertising or spend little or nothing on advertising after their name change, suggesting that a mere association with the current glamour style is enough to garner large and permanent fund flow increases for the mutual fund.

The fact that increased flows are associated with increased marketing expenditures is consistent with Jain and Wu (2000) and Sirri and Tufano (1998). However, in those two papers, increased marketing serves to highlight a fund's recent high performance. In contrast, the funds in our sample are quite average in terms of pre-name-change performance. Thus, investors appear to be deceived by the name-change funds advertising their "new" glamour style and are deceived even more by the name-change funds that spend more on advertising. In contrast to the fund managers, who are clearly rewarded via increased fee revenue, the investors in such name-change funds are not rewarded in terms of increased fund performance. We find that after a name change, the average funds' three-factor alpha is significantly negative.

Our result that investors' buying and selling behavior toward mutual funds is influenced by name changes is consistent with a growing body of literature that documents that investors are irrationally influenced by cosmetic effects. 
For example, Hirshleifer (2001) discusses recent evidence that irrelevant, redundant, or even old news affects security prices when presented saliently. ${ }^{1}$ In addition, our results that mutual fund managers time their name changes to take advantage of shifting investor sentiment is consistent with recent research that managers appear to understand stock market inefficiencies and take advantage of them through corporate actions such as equity issues, dividend issuance decisions, and mergers. ${ }^{2}$ Finally, our evidence is consistent with Barberis and Shleifer (2003) who argue that investors categorize risky assets into styles such as value and growth and move fund allocations among these styles based on their past performance.

This paper is organized as follows. In Section I, we discuss the data sources used to create the sample and describe the event study methodology. In Section II, we present the results, perform various robustness checks, and test various hypotheses related to the determinants of the fund flows. Section III concludes.

\section{Data and Methodology}

Table I describes the sample selection process. We use data from CRSP, Lipper, and Morningstar over the 1994 to 2001 period to identify name changes. ${ }^{3}$ We use the CRSP mutual funds database to create our initial cut of namechange funds. We sort all funds in CRSP on their Investment Company Data, Inc. (ICDI) number, and then keep track of name changes in the NAME field for the same ICDI number. The ICDI numbers, similar to the permanent numbers (PERMNO) in the CRSP individual stock database, are permanent, and thus allow us to track name changes for a given fund. This provides us with 15,972 name changes. Next, we screen on funds that have an apparent change by the fund's investment style as indicated in the fund's old/new name. Funds are defined as having a style name change if the new name is different from the old name by one of the following style identifiers: "value/val," "growth/gr/grth," "small/sm," and "large/lg." If a new name includes any of these phrases and the old name does not, then the name change is classified as a "to" name-change event. Similarly, if any of these phrases are dropped in the new name, then the name change is classified as a "from" name-change event. After retaining only funds with style name changes in the CRSP data, we are left with 935 name changes that are associated with an apparent change in the fund's investment style as indicated in the fund's old/new name.

A fund name change typically involves name changes in all the share classes of the fund. However, not all name-change funds have multiple share classes. Thus, following Chen et al. (2004) and Carhart et al. (2002), to avoid double counting, we retain only the primary share class of each fund, leaving us with

\footnotetext{
${ }^{1}$ See Cooper, Dimitrov, and Rau (2001), Huberman and Regev (2001), and Rashes (2001).

${ }^{2}$ See Baker and Wurgler (2000, 2002, 2004) and Shleifer and Vishny (2003).

${ }^{3}$ Due to the lack of monthly data in CRSP for some of the variables used in our study, our sample starts in 1994 .
} 
Table I

\section{Mutual Fund Name-Change Sample Description}

We use CRSP, Lipper, and Morningstar over the 1994 to 2001 period to identify name changes. We sort all funds in CRSP on their ICDI code, and keep track of name changes in the NAME field for the same ICDI code. We screen on funds that have an apparent change in the fund's investment style as indicated in the fund's old/new name. Funds are defined as having a style name change if the new name is different from the old name by one of the following style identifiers: "value/val," "growth/gr/grth," "small/sm" and "large/lg." If a new name includes any of these phrases and the old name does not, then the name change is classified as a "to" name-change event. Similarly, if any of these phrases are dropped in the new name, then the name change is classified as a "from" name-change event.

\begin{tabular}{lr}
\hline & Number \\
\hline Initial number of mutual fund name changes in sample period & 15,972 \\
Number of style name changes & 935 \\
Number of style name changes for primary share class funds & 490 \\
Number of style name changes with available dates & 348 \\
Number of style name changes (equity funds only) & 332 \\
Number of unique funds & 296 \\
"To" style name changes & 88 \\
To value & 68 \\
To growth & 44 \\
To small & 41 \\
To large & \\
"From" style name changes & 20 \\
From value & 60 \\
From growth & 8 \\
From small & 3 \\
From large & \\
\hline
\end{tabular}

490 events. Next, we use data provided by Morningstar and Lipper to identify the month of the name change. The data from Lipper and Morningstar include both the new and old names, along with the effective dates of the name changes. We retain the fund in the sample only if the dates of the name change are available and are within 1 month of each other in the Morningstar and Lipper databases. We use the earlier of the two dates as the announcement date if the dates do not match; this reduces the sample to 348 events. Lastly, restricting the population to only equity mutual funds yields a final sample of 332 style name changes over the April 1994 to July 2001 period. As reported in Table I, we identify 108 (128) cases in which the term "value" ("growth") is added to or dropped from the fund's name and 52 (44) cases in which the term "small" ("large") is added to or dropped from the fund's name. As some name changes involve more than one style, these 332 name-change events are associated with 296 funds. The Appendix lists a random sample of 25 funds that changed their names, including the fund's old name, new name, and resulting name-change category. For example, the "Gabelli Global Interactive Couch Potato Fund" changed its name to "Gabelli Global Growth Fund," adding a 
"growth" to its name, thus earning itself a name-change categorization of "To growth."

Many of the name changes in our sample correspond to large changes in the value/growth and small cap/large cap premiums over this period. Figure 1 graphs data on the quarterly distribution of these name changes over our sample period. Each panel in the figure plots the number of name changes toward a particular category and away from the opposite category. The panel also reports the 3-month lagged difference between the return to the style the fund changes to and the return to the style the fund changes away from (using size and book-to-market (B/M) quintile portfolio returns from Ken French's Web site). For example, Panel A reports the number of name changes toward value and away from growth. It also reports the 3-month lagged difference in returns between value (the highest $\mathrm{B} / \mathrm{M}$ quintile portfolio) and growth (the lowest $\mathrm{B} / \mathrm{M}$ quintile portfolio). Name changes tend to occur in waves: Roughly $45 \%$ of the funds in our sample make a name change in the 2000 to 2001 period alone. More interestingly, the panels show that funds tend to change their name to associate themselves with the current high-return style and/or to disassociate themselves from the current low-return styles. For example, as illustrated in Panel A, in the fourth quarter of 2000, the value portfolio earned $22.4 \%$ in excess of the growth portfolio; over the subsequent quarter (Q1 2001), 12 funds changed names to include "value" in the new name and seven funds dropped "growth" from their names. During the same period, only two funds changed names to include "growth" in the new name and two funds dropped "value" from their names. We analyze the relation between lagged style premiums and subsequent name changes more formally in the next section.

\section{Results}

\section{A. Descriptive Statistics}

Table II, Panel A reports the mean and median characteristics both for the name-change fund sample and for the universe of all other equity funds, matched on the date of the name change. We report data on lagged returns, excess returns, standard deviation of returns, TNA, fund flows, expenses, fees, and the fund age in months.

As in Sirri and Tufano (1998), we define the fund flow over the period $t-1$ to $t$ by the formula

$$
\text { Fund Flow }=\left[\mathrm{TNA}_{t}-\left(1+r_{t}\right) \mathrm{TNA}_{t-1}\right] / \mathrm{TNA}_{t-1},
$$

where TNA $_{t}$ is a fund's TNA at time $t$, and $r_{t}$ is the fund's return over the prior month. The daily Fama-French three-factor alpha (Fama and French (1993)) is calculated for each fund using up to 24 months of daily returns data prior to the date of the name change, with a minimum of 2 months of data required to compute the alpha. Daily fund total returns are obtained from the Wall Street Web 

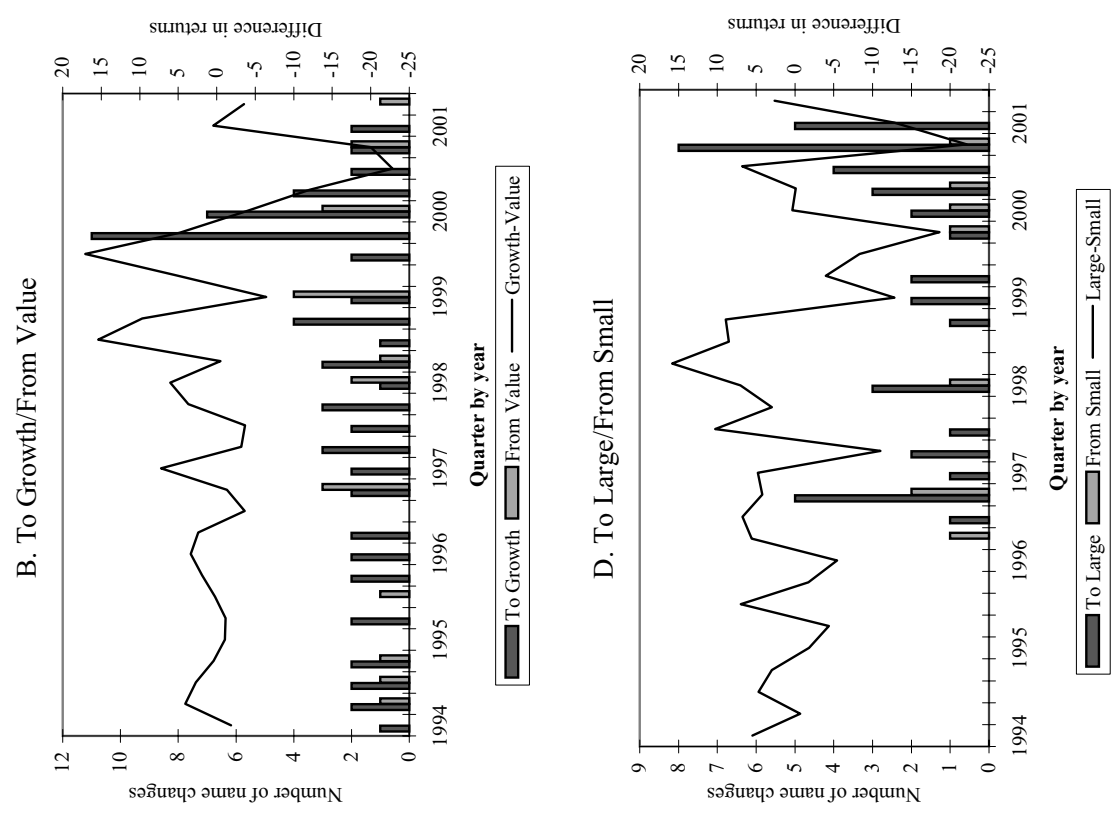

협.

ते

๘

ฮี

D

कृ ?

$\stackrel{7}{0}$

\%

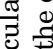

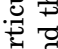

๘

ธิ

굴

3 웅

4

๑)

త్

\&

ฮี่ ฮี

प्त

केष

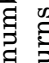

幽

of.

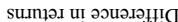

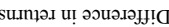
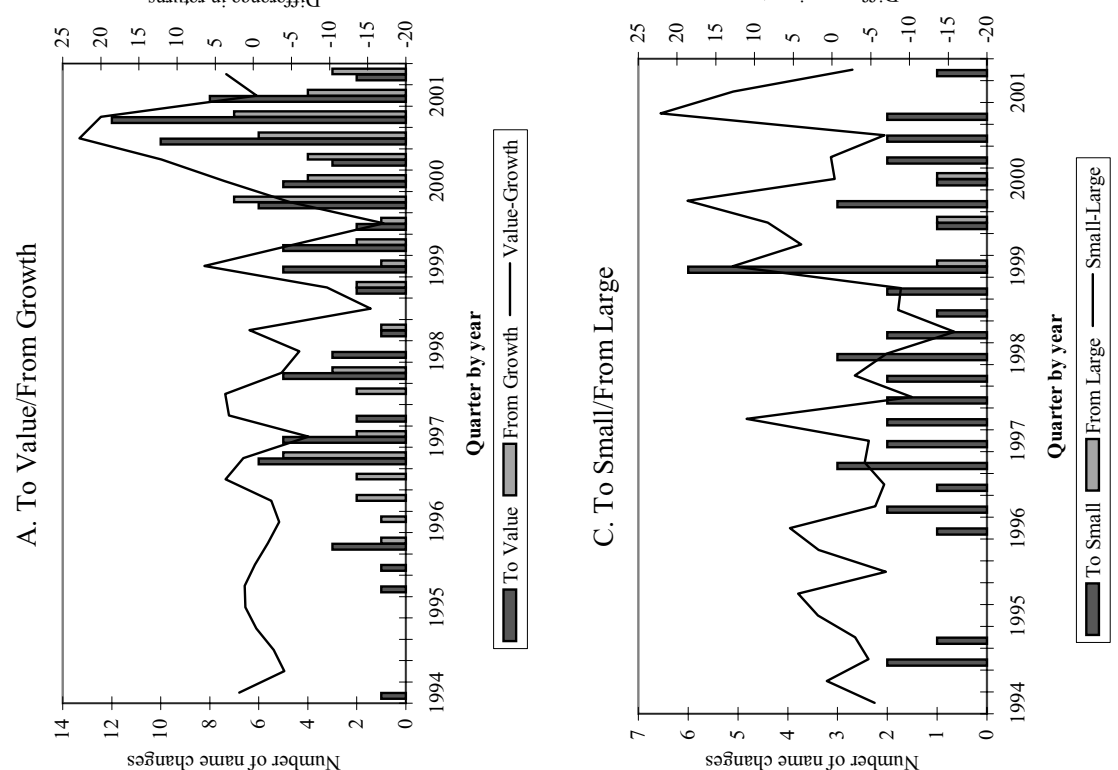

둥

ए)

ฉ:

दु वृ

国

$>$ 元

응

3

do

过

ฮี 을

है

롤

$\exists$

ซ

壱

0

-

¿ 응 


\section{Table II \\ Characteristics of Name-Change Funds Relative to the Universe of Mutual Funds}

Panel A reports the mean and median characteristics for the name-change fund sample and for the universe of all other equity funds, matched on the date of the name change. Since funds are aligned on the name-change months, the lagged values represent the fund characteristics just before the name change. Fund lagged returns are geometric returns computed by compounding 1 month returns over an $N$ month period. Fund flow is defined, as in Sirri and Tufano (1998), as $\left[\mathrm{TNA}_{t}-\left(1+r_{t}\right) \mathrm{TNA}_{t-1}\right] / \mathrm{TNA}_{t-1}$. The Fama-French three-factor alpha is calculated using daily returns over the 24 months prior to the date of the name change. If the fund does not have 24 months of data before the name-change month, all available data is used as long as there is at least 2 months of data. The fund age is the number of months that the fund has been in existence up to the event month and is calculated using the FIRST_DATE variable in the CRSP mutual fund database. The total load is the total of all maximum front, deferred, and redemption fees as a percentage total of loads applied to a fund. The expense ratio (over the calendar year) is the percentage of the total investment that shareholders pay for the mutual fund's operating expenses. The $12 \mathrm{~b}-1$ fee is a charge which is deducted from the underlying mutual fund's total assets to cover the cost of distribution and marketing. The value reported is the annual percentage of total assets attributed to this expense as of fiscal year-end as reported in the prospectus. These variables are obtained, respectively, from the TOT_LOAD, EXPENSES, and _12_B1 variables in the CRSP mutual fund database. Panel B reports the counts of name-change funds sorted into quintiles based on breakpoints obtained from the characteristics of the universe of all equity funds (excluding the name-change funds). For each name change, the quintile breakpoints are determined relative to all other funds on the event date. Quintile 1 is the smallest and 5 the largest. The panel also reports $p$-values from a $\chi^{2}$ one-sample test to test whether the characteristics of the mutual funds are uniformly distributed with respect to the universe of funds. Panel $\mathrm{C}$ reports load and expense data for the mutual fund sample and the universe of equity mutual funds. The panel also reports $p$-values for a Mann-Whitney nonparametric test to test the equality of the distribution for the sample and the universe.

Panel A: Mean and Median Characteristics on the Date of the Name Change

\begin{tabular}{|c|c|c|c|c|}
\hline & \multicolumn{2}{|c|}{ Name-Change Funds } & \multicolumn{2}{|c|}{ Other Funds } \\
\hline & Mean & Median & Mean & Median \\
\hline Fund 1-month lagged return (\%) & 1.15 & 0.75 & 0.73 & 0.89 \\
\hline $\begin{array}{l}\text { Fund 1-month lagged total net assets } \\
(\$ \text { millions })\end{array}$ & 299.42 & 89.53 & 598.84 & 68.42 \\
\hline Fund 1-month lagged flow (\%) & -0.47 & -0.52 & 1.15 & 0.12 \\
\hline Total 1-month lagged load (\%) & 2.24 & 0.00 & 2.43 & 1.00 \\
\hline $\begin{array}{l}\text { One month-lagged expenses } \\
\text { (percentage per year) }\end{array}$ & 1.32 & 1.27 & 1.54 & 1.45 \\
\hline $\begin{array}{l}\text { One month-lagged } 12 \mathrm{~b}-1 \text { fees } \\
\quad \text { (percentage per year) }\end{array}$ & 0.18 & 0.06 & 0.37 & 0.25 \\
\hline Fund return over past 6 months (\%) & 9.78 & 8.54 & 5.55 & 5.53 \\
\hline $\begin{array}{l}\text { Standard deviation of fund returns } \\
\text { over past } 12 \text { months }(\%)\end{array}$ & 5.42 & 4.81 & 5.21 & 4.60 \\
\hline Mean fund flow over past 6 months (\%) & 0.00 & -0.27 & 1.39 & 0.31 \\
\hline $\begin{array}{l}\text { Fama-French three-factor alpha } \\
\text { calculated over the past } 24 \text { months }(\%)\end{array}$ & -0.11 & -0.12 & 0.27 & -0.11 \\
\hline Fund age in months & 107.46 & 68 & 72.68 & 46 \\
\hline
\end{tabular}


Table II-Continued

Panel B: Counts of Name-Change Funds Sorted into Quintiles Based on Breakpoints Obtained from the Characteristics of the Universe of All Equity Funds

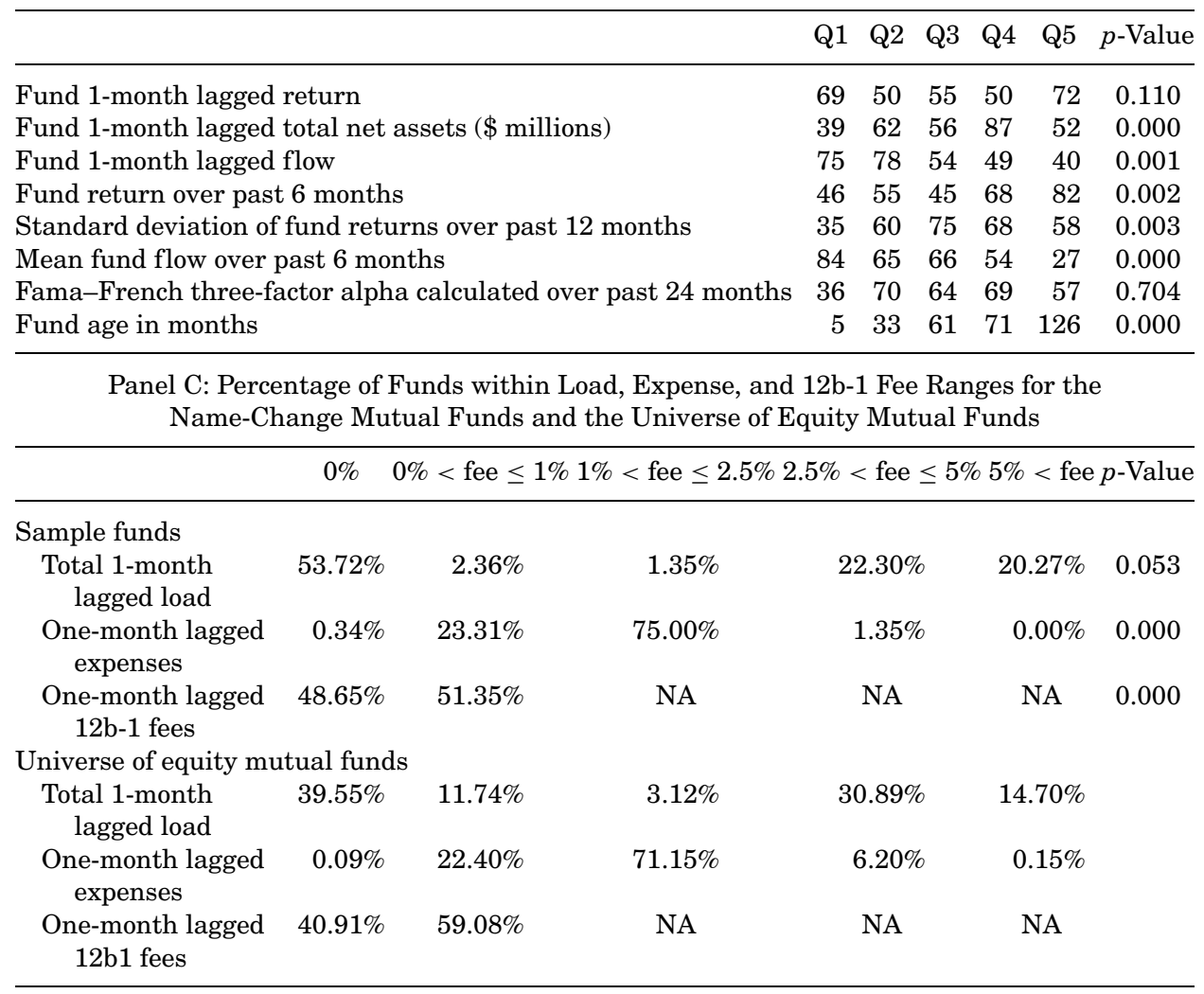

returns database, described in Goetzmann, Ivković, and Rouwenhorst (2001). ${ }^{4}$ The total load is the total of all maximum front, deferred, and redemption fees applied to a fund. The expense ratio (over the calendar year) is the percentage of the total investment that shareholders pay for the mutual fund's operating expenses. The $12 \mathrm{~b}-1$ fee is a charge which is deducted from the underlying mutual fund's total assets to cover the cost of distribution and marketing. The value reported is the annual percentage of total assets attributed to this expense as of the fiscal year-end, as reported in the prospectus. The fund age is the number of months that the fund has been in existence up to the event month and is calculated using the FIRST_DATE variable in the CRSP mutual fund database.

Prior to the name change, both on a mean and median level, the name-change funds appear to charge slightly lower 12b-1 fees, earn higher 6-month raw

\footnotetext{
${ }^{4}$ We would like to thank Will Goetzmann and the Yale International Center for Finance for providing us with access to this data.
} 
returns, and earn lower three-factor alphas than the corresponding fund in the equity universe. The name-change funds are also typically older; the median fund in our sample is 22 months older than the median fund in the universe (matched at the time of the name change). Most importantly, the name-change funds experience negative fund flows over both the 1- and 6-month periods before the name change, in comparison to the average equity fund in the universe.

To check whether these funds are typical of funds in the universe, we report in Panel B the number of name-change funds within each quintile based on breakpoints obtained from the characteristics of the universe of all equity funds (excluding the name-change funds). For each name change, the quintile breakpoints are determined relative to all other funds on the event date. Quintile one (Q1) is the smallest and five the largest. The panel also reports $p$-values from a $\chi^{2}$ one-sample test to test whether the counts of the name-change funds are uniformly distributed across the quintiles. The name-change funds earn similar 1-month lagged returns and excess returns (as measured by the FamaFrench three-factor alpha) as the universe-the one-sample test is unable to reject the hypothesis that the quintile distribution is uniform. They earn higher returns over the 6 months before the name change-more than half the funds fall into the largest two quintiles. ${ }^{5}$ They are typically larger-approximately half the funds fall into the largest two quintiles for TNA. The name-change funds are older-two-thirds of the sample falls into the largest two quintiles for fund age. They have slightly higher standard deviations-more than twothirds of the sample falls into the upper three quintiles. Finally, they experience a much lower fund inflow than is typical in the universe-both over 1 month and 6 months, approximately half the name-change funds lie in the smallest two quintiles.

Our data on expenses and loads are typically discrete-there is significant clustering of loads and fees around $0 \%, 0.5 \%$, and so on. Panel $\mathrm{C}$ therefore reports load and expense data for the mutual fund sample and the universe of equity mutual funds, sorted into absolute bins. ${ }^{6}$ The panel also reports $p$-values for a Mann-Whitney nonparametric test to test the equality of the distribution for the sample and the universe. The sign of the statistics for all the three variables is negative- the distribution of these variables for the name-change funds is on the left of those of other funds. In other words, the name-change funds have significantly lower expenses and 12b-1 fees before the name change. The total load is marginally significant at the $6 \%$ level.

\section{B. What Type of Funds Change Their Names, and When?}

To get a more precise idea of what kinds of funds change their names and when they choose to do so, Table III reports results for two types of logistic regressions. Using a cross-sectional logistic regression, in Panel A we

\footnotetext{
${ }^{5}$ Six-month returns are geometric returns computed over an $N$-month period using the formula $\left(1+r_{1}\right) \times\left(1+r_{2}\right) \times\left(1+r_{3}\right) \times\left(1+r_{4}\right) \times\left(1+r_{5}\right) \times\left(1+r_{6}\right)-1$, where $r_{n}$ is the return in month $n$.

${ }^{6}$ According to SEC rules, while asset-based $12 \mathrm{~b}-1$ fees may not exceed $0.75 \%$ annually, service fees of no more than $0.25 \%$ may be added to pay for continuing shareholder service. Thus, actual maximum $12 \mathrm{~b}-1$ fees are $1 \%$ per year.
} 
investigate what kinds of funds choose to change their names. Using data from the month of the name change, we assign a dummy of 1 to the name-change fund and a 0 to all the remaining non-name-change equity funds in the universe. This is our dependent variable. We then stack the data across the name-change events to create our sample for Panel A. Consistent with the patterns reported in Table II, the mean fund flow over the 6 months prior to the name change is significantly negatively related to the likelihood that a fund will change its name. In addition, $12 \mathrm{~b}-1$ marketing fees and three-factor model alphas are negatively related to the likelihood of a name change. Finally, the age of the fund is positively related to the likelihood of a name change. To summarize,

\section{Table III}

\section{Determinants of Mutual Fund Name Changes}

This table reports results for logistic regressions to investigate the characteristics of funds that change their names. Panel A investigates what types of funds choose to change their names. It reports the results of a cross-sectional logistic regression estimated as follows: We assign the namechange fund a dummy of 1 , and others 0 and regress this on control variables that proxy for the fund performance, advertising, and other expenses. Explanatory variables are as defined in Table II. Panel B investigates, only for the sample of name-change mutual funds, at what point in their life cycle do the funds choose to change their names. We report results for a time-series logistic regression broken down into "to" and "from" name changes. We use all the time-series data available for each fund and regress the lagged explanatory variables on a dummy equal to 1 for the name-change month and 0 otherwise. $p$-Values are in parentheses.

Panel A: Cross-sectional Logistic Regression

Constant

$-8.05$

$(0.00)$

Log of fund 1-month lagged total net assets (\$ millions)

$-0.05$

(0.44)

0.00

$(0.97)$

$-0.01$

(0.39)

0.03

(0.22)

$-0.04$

(0.68)

$-1.42$

(0.00)

0.00

(0.61)

0.00

(0.87)

$-0.05$

(0.00)

$-0.67$

(0.00)

0.81

(0.00)

Log of fund age in months 
Table III-Continued

\begin{tabular}{|c|c|c|c|c|c|c|c|c|}
\hline \multicolumn{9}{|c|}{ Panel B: Time-Series Logistic Regression for Name-Change Funds } \\
\hline & \multicolumn{4}{|c|}{ To } & \multicolumn{4}{|c|}{ From } \\
\hline & (1) & (2) & (3) & (4) & (5) & (6) & (7) & (8) \\
\hline Constant & $\begin{array}{c}-4.24 \\
(0.00)\end{array}$ & $\begin{array}{r}-4.22 \\
(0.00)\end{array}$ & $\begin{array}{c}-3.92 \\
(0.00)\end{array}$ & $\begin{array}{c}-3.88 \\
(0.00)\end{array}$ & $\begin{array}{c}-4.12 \\
(0.00)\end{array}$ & $\begin{array}{r}-4.10 \\
(0.00)\end{array}$ & $\begin{array}{c}-3.99 \\
(0.00)\end{array}$ & $\begin{array}{r}-3.90 \\
(0.00)\end{array}$ \\
\hline $\begin{array}{l}\text { Log of fund 1-month lagged } \\
\text { total net assets (\$ millions) }\end{array}$ & & & $\begin{array}{c}-0.27 \\
(0.00)\end{array}$ & $\begin{array}{c}-0.27 \\
(0.00)\end{array}$ & & & $\begin{array}{c}-0.14 \\
(0.32)\end{array}$ & $\begin{array}{r}-0.14 \\
(0.29)\end{array}$ \\
\hline $\begin{array}{l}\text { Fund excess returns over } \\
\text { matching fund in past } \\
6 \text { months }\end{array}$ & & $\begin{array}{c}0.37 \\
(0.50)\end{array}$ & & $\begin{array}{c}0.35 \\
(0.47)\end{array}$ & & $\begin{array}{r}-0.74 \\
(0.41)\end{array}$ & & $\begin{array}{r}-0.79 \\
(0.40)\end{array}$ \\
\hline $\begin{array}{l}\text { Standard deviation of fund } \\
\text { returns over past } 12 \text { months }\end{array}$ & & & $\begin{array}{c}3.96 \\
(0.08)\end{array}$ & $\begin{array}{c}3.80 \\
(0.09)\end{array}$ & & & $\begin{array}{c}2.92 \\
(0.54)\end{array}$ & $\begin{array}{c}2.13 \\
(0.66)\end{array}$ \\
\hline $\begin{array}{l}\text { Mean fund flow over past } \\
6 \text { months }\end{array}$ & $\begin{array}{c}-3.52 \\
(0.00)\end{array}$ & $\begin{array}{r}-3.47 \\
(0.00)\end{array}$ & $\begin{array}{c}-3.46 \\
(0.00)\end{array}$ & $\begin{array}{c}-3.44 \\
(0.00)\end{array}$ & $\begin{array}{c}-9.30 \\
(0.00)\end{array}$ & $\begin{array}{r}-9.70 \\
(0.00)\end{array}$ & $\begin{array}{r}-10.13 \\
(0.00)\end{array}$ & $\begin{array}{r}-9.84 \\
(0.00)\end{array}$ \\
\hline $\begin{array}{l}\text { Fama-French three-factor alpha } \\
\text { calculated over the past } \\
24 \text { months }\end{array}$ & $\begin{array}{r}-1.79 \\
(0.88)\end{array}$ & $\begin{array}{c}-4.70 \\
(0.70)\end{array}$ & $\begin{array}{c}-0.54 \\
(0.97)\end{array}$ & $\begin{array}{c}-3.04 \\
(0.78)\end{array}$ & $\begin{array}{c}5.03 \\
(0.75)\end{array}$ & $\begin{array}{c}9.03 \\
(0.59)\end{array}$ & $\begin{array}{c}8.37 \\
(0.55)\end{array}$ & $\begin{array}{c}12.71 \\
(0.42)\end{array}$ \\
\hline $\begin{array}{l}\text { Return to the corresponding } \\
\text { style over the past } 6 \text { months }\end{array}$ & $\begin{array}{l}1.32 \\
(0.02)\end{array}$ & $\begin{array}{l}1.27 \\
(0.03)\end{array}$ & $\begin{array}{l}1.46 \\
(0.01)\end{array}$ & $\begin{array}{l}1.40 \\
(0.01)\end{array}$ & $\begin{array}{c}-1.40 \\
(0.08)\end{array}$ & $\begin{array}{r}-1.32 \\
(0.09)\end{array}$ & $\begin{array}{c}-1.40 \\
(0.07)\end{array}$ & $\begin{array}{r}-1.35 \\
(0.09)\end{array}$ \\
\hline
\end{tabular}

older funds, with more negative excess returns that have historically spent less on marketing, are more likely to change the names of their funds when fund inflows drop.

In Panel B, we investigate, only for the sample of name-change mutual funds, at what point in their life cycle do the funds choose to change their names. We report results for a time-series logistic regression across the name-change funds. We use all the time-series data available for these funds and regress a dummy for the name-change month on the lagged explanatory variables. In other words, for every name-change fund, the left-hand side variable takes the value of 1 at the name-change month and 0 in all other months. We report separate regressions for "to" style changes and "from" style changes.

The most important determinant of a name change is the fund flow-across all our specifications, the lagged 6-month mean fund flow is significantly negatively related to the likelihood that a fund will change its name. "To" namechange fund managers appear to time their name changes to occur after increases in the investment styles that are implied by the funds' new names. Similarly, "from" name-change managers appear to time their name changes to occur after decreases in the investment styles that were implied in the funds' old names. This is evident in the positive and significant loadings on the lagged 6-month style premiums in all four "to" regression specifications, and in the negative (but only significant at the 10\% level) loadings on all four "from" specifications.

In other words, when a particular style premium is earning a high 8-month lagged return, the fund is more likely to switch to this style. Similarly, when the style premium is low, the fund is more likely to switch away from this style. 
From the standpoint of the fund manager, the results in Table III tell a simple story: The inflows to a fund may be down because the fund is not outperforming the market on a risk-adjusted basis. If investors treat the name-change fund as a new fund, particularly one associated with a hot style, the change in name may stem the decline in inflows.

\section{The Impact of Name Changes on Abnormal Fund Flows}

The fund flow literature has shown that investors tend to base their fund purchase decisions on prior performance (Spitz (1970), Smith (1978), Warther (1995), and Chevalier and Ellison (1997)). This performance-flow relationship is nonlinear in that investors direct their investments to funds that perform well in the recent past but fail to direct investments away from poorly performing funds (Ippolito (1992), Gruber (1996), Carhart (1997), Goetzmann and Peles (1997), Sirri and Tufano (1998), and Lynch and Musto (2003)). In addition, minimization of search costs appears to be important to investors: Holding performance constant, funds that spend money to advertise their past good performance tend to attract more inflows than other funds (Sirri and Tufano (1998)).

To control for these factors, we use a propensity score algorithm (see Villalonga (2004) or Hillion and Vermaelen (2004)) to estimate abnormal flows to our sample. Propensity score matching algorithms are becoming increasingly popular to construct suitable control groups in nonexperimental studies. This is because no constraints need to be imposed on the matching variables. More importantly, they accommodate a high number of matching variables. The task of constructing a matched sample becomes impossible when there are several characteristics in which the treatment and control groups differ. Since we need to control for fees, loads, performance, TNA, and other characteristics, the propensity score methodology offers a parsimonious approach to obtaining matching funds to compute abnormal flows. ${ }^{7}$

To estimate a propensity score for each fund, we estimate a logistic regression for each event date by assigning the dependent variable for each namechange fund a dummy of 1 , and all other funds 0 . We use the following independent variables: the 1-month lagged log of TNA, 6-month return to the fund before the name-change month, average fund flow and standard deviation of returns over the 6 months before the name change, the 12b-1 marketing fees before the name change, the Fama-French three-factor alpha of the fund (calculated using daily data over the 2 years before the name change), and the $\log$ of the age of the fund in months. For each name-change fund, a matching

\footnotetext{
${ }^{7}$ An alternative methodology to compute abnormal flows would be to develop a model of expected fund flows based upon multiple factors (such as performance, fees, etc.) and calculate the abnormal flows to a fund as the realized flows minus the expected flows. However, a potential weakness to this approach is that shocks that change expectations around the name change would result in nonstationarity in the model's estimated parameters, and thus give incorrect expected flow estimates. In contrast, the propensity-score matching method may be more accurate, given that most unanticipated shocks should be impounded in both the name-change fund and the matching fund.
} 
no-name-change fund is identified as the fund with the closest propensity score to the name-change fund. Abnormal fund flows are computed for each namechange fund in our sample with respect to their matching fund.$^{8}$

Panel A of Table IV reports CAFs to all name-change funds, hot style namechange funds and cold style name-change funds. Hot style name changes are defined as name changes toward (away from) a particular style when the corresponding style premium is up (down). Cold style name changes are defined as name changes away from (toward) a particular style when the corresponding style premium is up (down).

To make these classifications, we use size and B/M quintile portfolio returns from Ken French's Web site. For "value" name changes, we use the highest B/M quintile portfolio; for "growth," we use the lowest B/M quintile portfolio; for "large," we use the highest size quintile portfolio; and for "small," the lowest size quintile portfolio. For every name-change fund, in the event month we first calculate the holding period return to the corresponding style portfolio over months -6 to -1 relative to the name change. If a name change is a "to" ("from") name change and the lagged 6-month return to the corresponding style is positive, the name change is classified as a hot style (cold style) name change. Similarly, a "to" ("from") name change accompanied by a negative lagged 6-month return to the corresponding style, is classified as a cold style (hot style) name change. We calculate CAFs to measure the fund flow performance over various event windows before and after the name-change periods. In each event month, individual fund percentage abnormal flows over the corresponding matching funds are averaged to obtain an overall percentage flow measure for that month. Then these monthly flows are cumulated for the specified event period to obtain a CAF for that period.

As reported in the first row of Table IV Panel A, in the year prior to the name change, the funds do not experience statistically significant abnormal flows, suggesting the propensity score algorithm does a good job in finding matching funds. In contrast, in the year after the name change, the increase in abnormal flows is quite striking. CAFs in excess of those earned by a matching fund are $20.17 \%$ in the year after the name-change month. A greater number of funds make hot style changes (206 or $65 \%$ ) than make cold style changes (111 or $35 \%){ }^{9}$

\footnotetext{
${ }^{8}$ Later in this paper we also describe our results using raw and median flow measures.

${ }^{9}$ There are a total of 296 funds in our sample, which represent 332 name-change events. Thus, there are funds in our sample which have multiple events for the same name change. For example, consider a hypothetical fund changing its name from "Sure-Fire Growth Fund" to "Sure-Fire Value Fund." This would be classified as both a "from growth" and a "to value" name change. To avoid potential biases from double counting the flows to such funds, in all rows of Table IV we count such funds only once in the calculation of abnormal flows. In addition, the total number of hot/cold style name changes will be greater than 296 , since a name change may be classified as both hot and cold. Using the previous name-change example, if the returns to both the value and growth portfolios have been positive, then the "from growth" part of the name change results in a cold classification (i.e., the name change is away from a current hot style), and the "to value" part of the name change results in a hot classification (i.e., toward a current hot style). To the extent that our classification scheme causes the same fund to be present in both the hot and cold styles, it should bias us against finding any difference between the two subsamples.
} 


\section{Table IV \\ Cumulative Abnormal Flows Earned by Funds Around the Name-Change Period}

This table reports average CAFs to the name-change funds in the year before to the year after the name change. Fund flow is defined as $\left[\mathrm{TNA}_{t}-\left(1+r_{t}\right) \mathrm{TNA}_{t-1}\right] / \mathrm{TNA}_{t-1}$. Abnormal fund flows are computed for each name-change fund in our sample with respect to the closest non-name-change mutual fund on the basis of its propensity score. Propensity scores are computed as follows: For each event date, we estimate a logistic regression by assigning the dependent variable for each namechange fund a dummy of 1 , and all other funds 0 . We use the following independent variables: the 1-month lagged log of total net assets, 6-month return to the fund before the name-change month, average fund flow and standard deviation of returns over the 6 months before the name change, the 12b-1 marketing fees before the name change, the Fama-French three-factor alpha of the fund (calculated using daily data over the 2 years before the name change), and the log of fund age in months. Panel A reports CAFs to all funds, "hot" style name-change funds, and "cold" style name-change funds. Hot style name changes are defined as name changes toward (away from) a particular style when the corresponding style premium is up (down). Cold style name changes are defined as name changes away from (toward) a particular style when the corresponding style premium is up (down). Panel B reports CAFs to "cosmetic" and "noncosmetic" name changes. A name change is defined as cosmetic (its new name is not an accurate description of its portfolio holdings) if its post-name-change beta loading on the appropriate Fama-French factor does not exceed a breakpoint loading. The breakpoints are based on the factor loadings obtained from regressing high and low quintile book-to-market and size portfolios on the daily three-factor model premiums. Panel C reports CAFs for a two-way sort between cosmetic and noncosmetic funds classified into hot and cold categories. A fund's name change can result in multiple event classifications (hot/cold or cosmetic/noncosmetic). Thus, the total number of hot and cold events in Panel A, the total cosmetic and noncosmetic events in Panel B, and the sum of events across Panels C.1 and C.2 will be greater than the 296 funds in our sample. In each panel, we report $t$-statistics (in parenthesis) for the null hypothesis that the event window abnormal flow is 0 . At the bottom of each panel, we also report $t$-statistics for tests of the null hypothesis of equality of mean abnormal flows across fund categories.

\begin{tabular}{|c|c|c|c|c|c|c|c|}
\hline & \multirow[b]{2}{*}{$N$} & \multicolumn{6}{|c|}{ Months } \\
\hline & & -12 to 0 & -6 to 0 & -3 to 0 & 0 to 3 & 0 to 6 & 0 to 12 \\
\hline \multicolumn{8}{|c|}{$\begin{array}{l}\text { Panel A: Cumulative Abnormal Flows for All Name Changes, Hot Style, } \\
\text { and Cold Style Name Changes }\end{array}$} \\
\hline All name changes & 296 & $\begin{array}{l}-0.45 \% \\
(-0.23)\end{array}$ & $\begin{array}{l}1.21 \% \\
(0.98)\end{array}$ & $\begin{array}{l}-0.25 \% \\
(-0.29)\end{array}$ & $\begin{array}{l}8.44 \% \\
(3.58)\end{array}$ & $\begin{array}{l}12.07 \% \\
(4.64)\end{array}$ & $\begin{array}{l}20.17 \% \\
(6.95)\end{array}$ \\
\hline Hot style name changes & 206 & $\begin{array}{l}0.84 \% \\
(0.35)\end{array}$ & $\begin{array}{l}1.73 \% \\
(1.12)\end{array}$ & $\begin{array}{l}0.09 \% \\
(0.08)\end{array}$ & $\begin{array}{l}12.42 \% \\
(3.78)\end{array}$ & $\begin{array}{l}17.05 \% \\
(4.78)\end{array}$ & $\begin{array}{l}27.63 \% \\
(7.06)\end{array}$ \\
\hline Cold style name changes & 111 & $\begin{array}{l}-4.32 \% \\
(-1.56)\end{array}$ & $\begin{array}{l}-0.45 \% \\
(-0.25)\end{array}$ & $\begin{array}{l}-1.35 \% \\
(-1.07)\end{array}$ & $\begin{array}{l}0.47 \% \\
(0.27)\end{array}$ & $\begin{array}{l}1.89 \% \\
(0.84)\end{array}$ & $\begin{array}{c}3.98 \% \\
(1.36)\end{array}$ \\
\hline $\begin{array}{l}T \text {-test for differences } \\
\quad(\text { hot-cold) }\end{array}$ & & 1.41 & 0.92 & 0.87 & 3.22 & 3.60 & 4.84 \\
\hline
\end{tabular}

Panel B: Cumulative Abnormal Flows for Cosmetic vs. Noncosmetic Name Changes

\begin{tabular}{lccccccc}
\hline Cosmetic & \multirow{2}{*}{195} & $-1.18 \%$ & $0.48 \%$ & $-0.21 \%$ & $9.99 \%$ & $13.46 \%$ & $22.84 \%$ \\
& & $(-0.51)$ & $(0.33)$ & $(-0.19)$ & $(3.16)$ & $(4.02)$ & $(6.23)$ \\
Noncosmetic & \multirow{2}{*}{115} & $2.64 \%$ & $1.89 \%$ & $-0.80 \%$ & $9.17 \%$ & $12.74 \%$ & $17.31 \%$ \\
& & $(0.87)$ & $(0.94)$ & $(-0.61)$ & $(1.93)$ & $(2.45)$ & $(3.07)$ \\
$T$-test for differences & & -1.01 & -0.56 & 0.35 & 0.14 & 0.12 & 0.82 \\
\hline
\end{tabular}


Table IV-Continued

\begin{tabular}{|c|c|c|c|c|c|c|c|}
\hline & \multirow[b]{2}{*}{$N$} & \multicolumn{6}{|c|}{ Months } \\
\hline & & -12 to 0 & -6 to 0 & -3 to 0 & 0 to 3 & 0 to 6 & 0 to 12 \\
\hline \multicolumn{8}{|c|}{ Panel C.1: Cumulative Abnormal Flows for Hot Style Cosmetic vs. Noncosmetic Name Changes } \\
\hline Cosmetic & 157 & $\begin{array}{l}0.25 \% \\
(0.10)\end{array}$ & $\begin{array}{l}1.33 \% \\
(0.80)\end{array}$ & $\begin{array}{l}0.17 \% \\
(0.14)\end{array}$ & $\begin{array}{l}12.08 \% \\
(3.13)\end{array}$ & $\begin{array}{l}16.10 \% \\
(3.95)\end{array}$ & $\begin{array}{c}27.18 \% \\
(6.14)\end{array}$ \\
\hline Noncosmetic & 52 & $\begin{array}{l}4.81 \% \\
(0.90)\end{array}$ & $\begin{array}{l}1.43 \% \\
(0.40)\end{array}$ & $\begin{array}{l}-1.18 \% \\
(-0.51)\end{array}$ & $\begin{array}{l}21.77 \% \\
(2.15)\end{array}$ & $\begin{array}{c}27.96 \% \\
(2.58)\end{array}$ & $\begin{array}{c}35.29 \% \\
(3.09)\end{array}$ \\
\hline$T$-test for differences & & -0.77 & -0.03 & 0.52 & -0.90 & -1.03 & -0.66 \\
\hline \multicolumn{8}{|c|}{ Panel C.2: Cumulative Abnormal Flows for Cold Style Cosmetic vs. Noncosmetic Name Changes } \\
\hline Cosmetic & 44 & $\begin{array}{l}-7.90 \% \\
(-1.77)\end{array}$ & $\begin{array}{l}-3.64 \% \\
(-1.24)\end{array}$ & $\begin{array}{l}-2.37 \% \\
(-1.04)\end{array}$ & $\begin{array}{l}0.97 \% \\
(0.41)\end{array}$ & $\begin{array}{l}1.78 \% \\
(0.61)\end{array}$ & $\begin{array}{l}4.24 \% \\
(1.08)\end{array}$ \\
\hline Noncosmetic & 66 & $\begin{array}{l}-0.42 \% \\
(-0.12)\end{array}$ & $\begin{array}{l}1.22 \% \\
(0.55)\end{array}$ & $\begin{array}{l}-0.77 \% \\
(-0.52)\end{array}$ & $\begin{array}{l}-0.73 \% \\
(-0.36)\end{array}$ & $\begin{array}{l}1.10 \% \\
(0.38)\end{array}$ & $\begin{array}{l}2.93 \% \\
(0.75)\end{array}$ \\
\hline$T$-test for differences & & -1.33 & -1.32 & -0.59 & 0.54 & 0.17 & 0.24 \\
\hline
\end{tabular}

Remarkably, we find that the increase in fund flow is entirely concentrated in funds that make a hot style name change. These funds earn significant CAFs of $12.42 \%$ in the 3 months after the name-change month, as compared to $0.47 \%$ for funds that made cold style name changes. Over the year after the name change, hot style funds earn CAFs of $27.63 \%$, as compared to an insignificant $3.98 \%$ for cold style funds. Over all periods after the name change, hot style funds earn significantly higher abnormal flows than cold style funds.

Next, we test whether there is a difference in flows when the name change is cosmetic in the sense that the fund's investing style, as reflected by the fund's new name, does not reflect its portfolio holdings, as opposed to noncosmetic name changes, such that the style implied in the fund's new name does match the holdings of the fund. In other words, we ask the question, "Are fund managers rewarded with increased flows if they simply change their name to reflect the current glamour style, even though the implied style of their fund's holdings is not reflected in their new name?" An efficient market should not reward a cosmetic name change with an increased fund flow.

We define cosmetic and noncosmetic name changes by computing postname-change fund-return factor loadings and then use those loadings to judge whether or not the funds are really following the investment styles implied by their names (similar to Lakonishok, Shleifer, and Vishny (1992)). Specifically, for each name-change event, we regress the daily fund excess returns over the 2 -year period after the name change (or all available data, if less then 2 years is available) on the daily values of the Fama-French three-factor model premiums. ${ }^{10}$ For each event, we keep track of the appropriate factor loading that

\footnotetext{
${ }^{10}$ The three Fama-French factors are Rm (the excess return on the market), SMB (a zeroinvestment portfolio that is long on small capitalization (cap) stocks and short on large cap stocks), and HML (a zero-investment portfolio that is long on high book-to-market (B/M) stocks and short on low B/M stocks). We thank Ken French for providing us this data. Details about the construction of the variables can be obtained from mba.tuck.dartmouth.edu/pages/faculty/ken.french/.
} 
corresponds to the fund's new name. For example, we retain the HML loading for a "to value" name change and the SMB loading for a "from small" name change. Next, we compute loadings for "pure" style funds in order to define cosmetic and noncosmetic breakpoints. We use high and low quintile B/M and size portfolios as our proxy for pure style funds. ${ }^{11}$ We regress daily excess returns of these portfolios on the daily three-factor model premiums to obtain breakpoints for each style loading (value, growth, small, and large). If a name-change fund's factor loading exceeds the breakpoint for a specific style, then that fund is deemed a noncosmetic fund (its new name is an accurate description of its portfolio holdings). ${ }^{12}$ If a name-change fund's factor loading does not exceed the breakpoint for a specific style then that fund is branded a cosmetic fund (its new name is not an accurate description of its portfolio holdings). ${ }^{13}$

Table IV, Panel B reports the event study CAFs broken down by cosmetic and noncosmetic classifications and Panels C.1 and C.2 report the cosmetic/noncosmetic classifications broken down into hot and cold name changes, respectively. ${ }^{14}$ The majority of name-change funds are cosmetic (63\%). ${ }^{15}$ Conditional on making a cosmetic name change, a much greater number of name changes are hot $(78 \%)$ rather than cold (22\%). Conditional on making a noncosmetic name change, $44 \%$ are hot and $56 \%$ are cold. These breakdowns on the percentages of name-change types are consistent with fund managers believing that they will earn increased flows from changing their fund name to be associated with the current glamour style, even if the new name does not accurately reflect their fund holdings.

The flow numbers support this conjecture. Rejecting the hypothesis that cosmetic name changes should not earn abnormal fund flows, we find in Panel $\mathrm{B}$ that over the 3 months after the name change, there is no statistical difference in the flows to cosmetic and noncosmetic name changes, with cosmetic funds garnering abnormal flows of $9.99 \%$ and noncosmetic funds experiencing inflows of $9.17 \%$. We find no difference in abnormal flows across the cosmetic and noncosmetic name-change types over any horizon.

Table IV, Panels C.1 and C. 2 report CAFs for the two-way sort between cosmetic and noncosmetic hot and cold name changes, respectively. Again, there

\footnotetext{
${ }^{11}$ We would like to thank Ken French for providing us with the daily portfolio returns.

${ }^{12}$ Using this approach, a fund is defined as a noncosmetic value fund if it has a loading of greater than 1.00 on HML; it is defined as a noncosmetic growth fund if it has a loading of less than -0.42 on HML; it is defined as a noncosmetic small fund if it has a loading of greater than 0.90 on SMB; and, it is defined as noncosmetic large fund if it has a loading of less than -0.27 on SMB. These cutoffs are consistent with factor loadings from Table I of Fama and French (1996).

${ }^{13}$ Computing the breakpoints for the cosmetic/noncosmetic definitions using the Fama-French quintile portfolios is a more conservative approach than using the decile portfolios, in terms of not upward biasing the number of funds classified as cosmetic. Specifically, estimating the cosmetic breakpoints using the decile portfolios of Fama-French will result in more extreme breakpoint loadings, thus classifying more funds as cosmetic.

${ }^{14}$ As noted earlier (see footnote 9 ), a fund's name change can be classified in various ways. Thus, the total number of cosmetic and noncosmetic funds in Table IV, Panel B, and the sum of events across Panel C.1 and Panel C.2, will be greater than the 296 unique funds in our sample.

${ }^{15}$ Consistent with our finding that a majority of our sample funds' names do not reflect their holdings, Lakonishok et al. (1992) show that the market betas of "value" funds are close to 1 and their returns are not correlated with a value portfolio.
} 
is no evidence that cosmetic name-change funds earn statistically lower flows than noncosmetic name-change funds. The only obvious pattern is that hot style name-change funds continue to earn significantly higher CAFs than cold style name-change funds.

Finally, we create a "change-in-holdings" measure which calculates the extent to which a fund changes its effective portfolio holdings from before to after the name change (not reported in the tables). We use this measure in combination with the previous cosmetic measure to examine the difference in flows among the four combinations of cosmetic/noncosmetic interacted with changein-holdings/no-change-in-holdings. We compute the change-in-holdings measure as follows: We use 2 years of daily returns before and after the name change (or all available data if less than 2 years, requiring a minimum of 2 months of daily returns) to estimate beta loadings for the Fama-French three-factor model in the pre- and post-name-change periods. From these beta estimates, we compute the squared differences on the appropriate pre- and post-SMB or HML loadings for every fund. For example, for a "to value" fund, we compute the squared differences on its pre- and post-HML loadings. We classify funds into "no-change-in-holdings" or "change-in-holdings" by comparing the namechange fund's squared difference in loadings to breakpoint values.

It might seem reasonable to define funds as "no-change-in-holdings" if the squared difference in loadings is close to 0 , but that would ignore changes in loadings which arise from noise in the fund return/three-factor premium relationship, thus upward biasing the number of "change" funds. To obtain a reasonable proxy for the shifts in factor loadings that are not due to changes in true style, we calculate the $95^{\text {th }}$ percentile of the distribution of the squared differences in loadings for each of the "pure" style portfolios (high and low quintile $\mathrm{B} / \mathrm{M}$ and size portfolios). To create the distribution, for each style we regress the daily excess returns of each portfolio on the three-factor model over an initial 2-year period and then again over a subsequent, contiguous 2-year period. We compute the squared difference in the loadings (HML for the B/M portfolios and SMB for the size portfolios) across these two periods. We roll forward 1 month and recompute the squared differences for each style. We continue rolling forward 1 month and reestimating the squared differences in loadings until we reach the end of our sample. We classify each name change into "nochange-in holdings" or "change-in-holdings" by comparing the funds' squared difference in loadings to the $95^{\text {th }}$ percentage point of the appropriate style's squared-difference-in-loadings distribution. If the name-change fund's squared difference is less than (greater or equal to) the $95^{\text {th }}$ percentage breakpoint, the fund is classified as "no-change-in-holdings" ("change-in-holdings"). ${ }^{16}$

Using this change-in-holdings measure, $44 \%$ of the funds have no effective change-in-holdings from before to after the name change. Perhaps, even more

\footnotetext{
${ }^{16}$ The average $95^{\text {th }}$ percentile point of the squared loading distribution for the pure style portfolios is 0.06 , implying that loading changes of up to 0.24 are consistent with noise. The quintile breakpoints of our name-change funds' squared difference in loadings are $q 20=0.011, q 40=$ 0.047 , q60 $=0.110$, and $\mathrm{q} 80=0.32$, placing 144 (186) of the name-change funds in the no-changein-holdings (change-in-holdings) category.
} 
striking, only $22 \%$ of our sample is classified as funds that actually do change their holdings and have a new name that accurately reflects their portfolio (i.e., "change-in-holdings/noncosmetic"). Interestingly, we find no statistical differences in the post-name-change flows across these four categories of changein-holdings/cosmeticity. All four categories experience statistically significant positive abnormal flows after the name change. For example, the "no-changein-holdings/cosmetic" funds earn CAFs of $23.97 \%$ over the year after the name change and "change-in-holdings/noncosmetic" funds earn $20.51 \%$ over the same period. As in our previous analysis that splits the funds only along the dimension of whether or not the fund's new name matches its holdings, we find that the only obvious pattern across all four categories is that hot style name-change funds earn significantly higher CAFs than cold style name-change funds. ${ }^{17}$

\section{Robustness Checks}

We first examine raw flows to funds to check if the patterns we see are artifacts of our matching methodology. Our results are qualitatively unchanged. Funds experience significantly positive raw flows in the year after the name change. Raw flows to all name-change funds are on the order of $20 \%$ in the year after the name-change month. Again, the increase in fund flow is almost entirely concentrated on funds that make a hot style name change. These funds earn significant cumulative raw flows of $24.37 \%$ in the year after the namechange month, as compared to $8.50 \%$ for funds that made cold style name changes. The difference between the two types of name changes is statistically significant across all periods after the name-change month.

Consistent with the abnormal flow results, we find that there is no difference in raw flows between cosmetic and noncosmetic funds over any of the post-name-change event windows. For example, funds making cosmetic and noncosmetic name changes experience raw flows of $22.41 \%$ and $16.19 \%$, respectively, over the year after the name change.

Second, we examine fund flows relative to the median flow of all equity mutual funds. Again, our results are qualitatively unchanged. As before, all of the significant post-name-change flows occur in the hot style changes, and we do not observe a difference in flows between cosmetic and noncosmetic names.

Third, Jayaraman, Khorana, and Nelling (2002) find significant changes in shareholder wealth and negative fund flows in the year after mutual fund mergers. We test that our abnormal flows are not being biased in month one of the name change due to a mechanical increase in flows from a fund merger. We do not believe that it is likely that our fund flow effects are related to fund mergers, since we require the fund ICDI number to be the same across the name-change period. Nonetheless, we estimate the abnormal flows using propensity-score matched funds for months 1 to 12 after the name change, removing month 0 from the abnormal flows. We find that the results are quite

\footnotetext{
${ }^{17}$ As a robustness test on the discrete two-state definitions of cosmetic/noncosmetic and changein-holdings, we examine continuous measures for both variables in Section II.E.
} 
robust to this control; from months 1 to 12 , all name-change funds experience an increase in abnormal flows of $17.36 \%$ ( $t$-statistic $=6.70)$. Again, hot name changes earn much greater flows than cold changes, at $23.75 \%$ and $3.22 \%$, respectively.

Fourth, we control for fund manager turnover. It may be the case that new managers attract increased flows, perhaps due to these funds advertising their new managers and investors subsequently believing that new management will bring increased performance to the fund. Thus, increases in fund flows would not be due to the fund's name change, but rather to investor reaction to the announcement of new fund management. To control for this potential upward effect on fund flows, we estimate abnormal flows for Table IV, Panel A by removing funds that experienced changes in fund management. Using the MGR_DATE variable in the CRSP mutual funds database, we identify 39 cases in which there was a change in management during the 6 months surrounding the name change. Interestingly, these funds experienced significantly more negative flows prior to the name change relative to funds that did not experience manager turnover ${ }^{18}$ _ perhaps fueling the manager's demise. For the remaining 257 funds, the results look very similar to the original Table IV, Panel A; the CAF during the year after the name change is $21.77 \%(t$-statistic $=$ 7.14) for all name changes, and again the difference between hot and cold style name changes is statistically significant, at $29.38 \%$ for hot and $4.98 \%$ for cold style changes, respectively.

Finally, we control for the effects of other investment style name changes in addition to the two dimensions of value/growth and small/large. Fund names often capture styles not spanned by these factors. We want to ensure that our evidence of abnormal flows is not driven by other styles that may also change in the value/growth and small/large name changes. To implement this, we reproduce the Table IV event study by excluding any name changes that also have another style implied in either the old or new name. ${ }^{19}$ The sample now contains 206 name-change funds, a reduction of 90 funds from the full sample. The abnormal flow results are robust to this change. The CAF during the year after the name change is $16.12 \%$ ( $t$-statistic $=5.12$ ) for all name changes, and again the difference between hot and cold style name changes is statistically significant, at $23.08 \%$ for hot and $1.27 \%$ for cold style changes. Also, as documented previously, the differences in abnormal flows between cosmetic and noncosmetic name changes are also not significant. In the year after the name change, the $\mathrm{CAF}$ is $18.91 \%$ for cosmetic name changes and is $13.40 \%$ for noncosmetic name changes, with the $t$-statistic for the difference being 0.84 . The differences in

\footnotetext{
${ }^{18}$ The 12-month CAF prior to the name change for a fund that experienced a change in management is $-14.16 \%$ while the average 12-month CAF for the other name-change funds is $1.64 \%$, with the difference in flows being statistically significant.

${ }^{19}$ Name changes involving one or more of the following terms in the old name but not the new name, or in the new name but not the old name, are excluded: income, core, strategic, U.S., select, capital appreciation, enhanced, balanced, alpha, timing, midcap, blue chip, long term, focus, low $\mathrm{P} / \mathrm{E}$, special, disciplined equity, emerging, aggressive, ultra, total return, one hundred, diversified, fundamental, index, OTC, contrarian, blend, and established.
} 
abnormal flows between cosmetic and noncosmetic name changes under the hot and cold classifications are not significant as well. The $t$-statistics for the differences in flows between cosmetic and noncosmetic name changes is -0.66 for the hot style name-change funds and 0.46 for the cold style name-change funds.

\section{E. What Determines Abnormal Flows to the Funds?}

Table V reports results for regressions of post-name-change CAFs to namechange funds in the 3 months after the name change on a number of variables. The first variable is a hot style dummy (equal to 1 if the name changes toward (away from) a particular style when the corresponding style premium is up (down), and 0 otherwise). The next variable is the cosmetic dummy (equal to 1 if a fund's new name accurately reflects its holdings, 0 otherwise). We include a "to" style dummy (equal to 1 if the move is to a particular style, and 0 otherwise) to check if the fund flows are different across "to" and "from" style name changes. Sirri and Tufano (1998) and Chevalier and Ellison (1997) show that an important determinant of abnormal inflows is past performance relative to the universe of funds. We control for the prior abnormal performance of the fund by including the decile ranking of the name-change fund's daily Fama-French three-factor alpha calculated over months -24 to -1 before the name change relative to the universe of all equity funds. To control for the raw performance of the fund, we also include the decile ranking of the namechange fund's 3 -month raw return from months -3 to -1 before the name change relative to the universe of all equity funds. Other control variables include the $\mathrm{CAF}$ over the matching fund from the -3 to -1 period before the name change, changes in 12b-1 fees, total load, and expense ratios between the 3 months before to the 3 months after the name change, the mean log of TNA over the -3 to -1 period before the name change, and the log of the fund age in months.

Across all models in Table $\mathrm{V}$, the hot style dummy is statistically significantly related to the CAFs earned by the fund. Funds changing their names to hot styles earn significantly higher flows than funds changing their names to cold styles. Consistent with the results in Table IV, the cosmetic measure is never significant in any regression in Table V. Cosmetic and noncosmetic name-change funds earn similar fund flows.

In Table IV and in the regressions in Table V so far, funds are assigned to cosmetic or noncosmetic categories depending on whether the post-name-change Fama-French loadings exceed the loadings of the relevant pure style indices. Similarly, our definition of funds that change their holdings from pre- to postname-change (i.e, the "change-in-holdings" measure) relies upon a potentially arbitrary cutoff. Thus, our methodology might mislabel some noncosmetic funds as cosmetic or some change-in-holdings funds as no-change-in-holdings when they do actually change their portfolios. To the extent that this occurs, we may be falsely concluding that abnormal flows to these funds are irrational when, in fact, the increase in inflows may be a rational response to noncosmetic changes. 


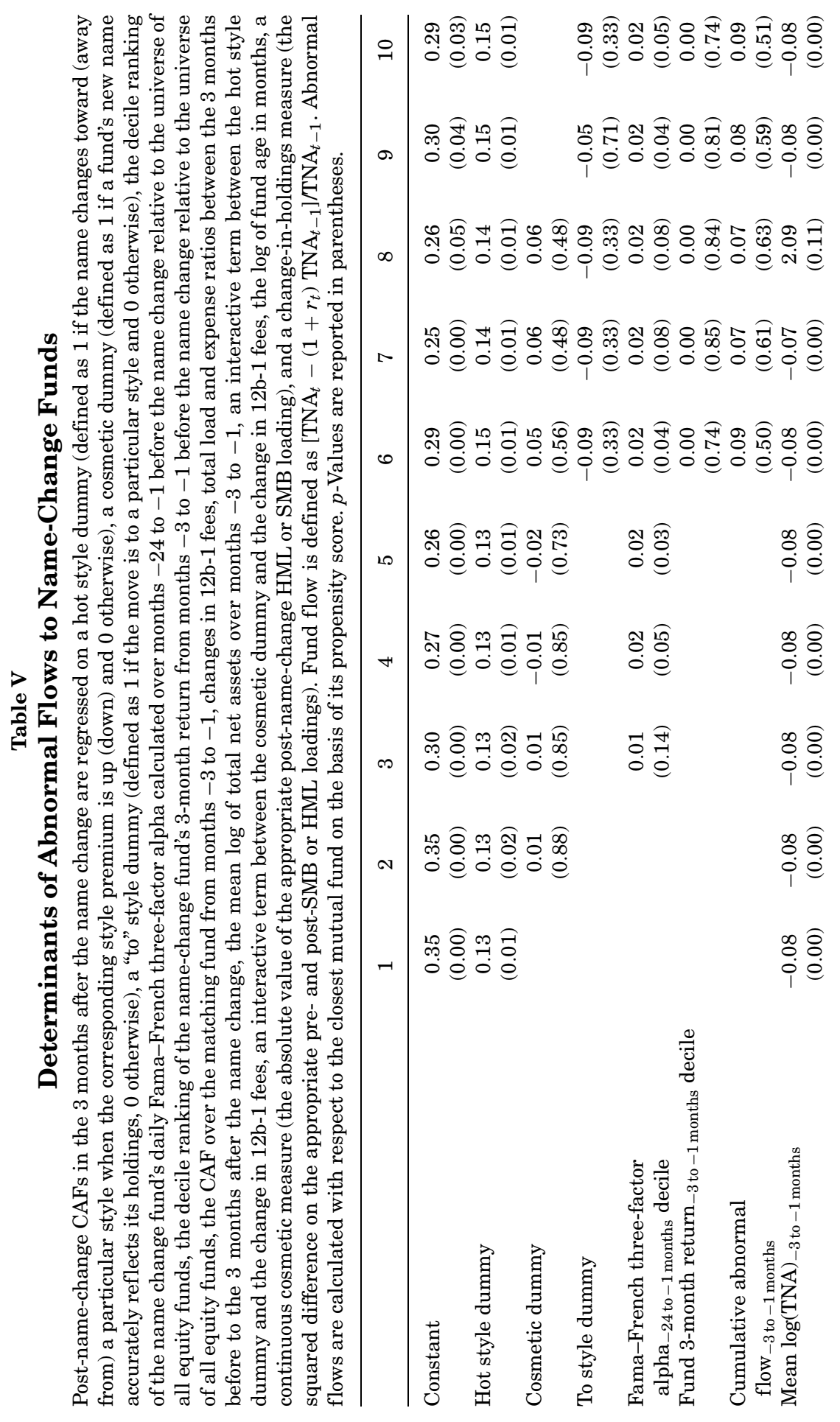




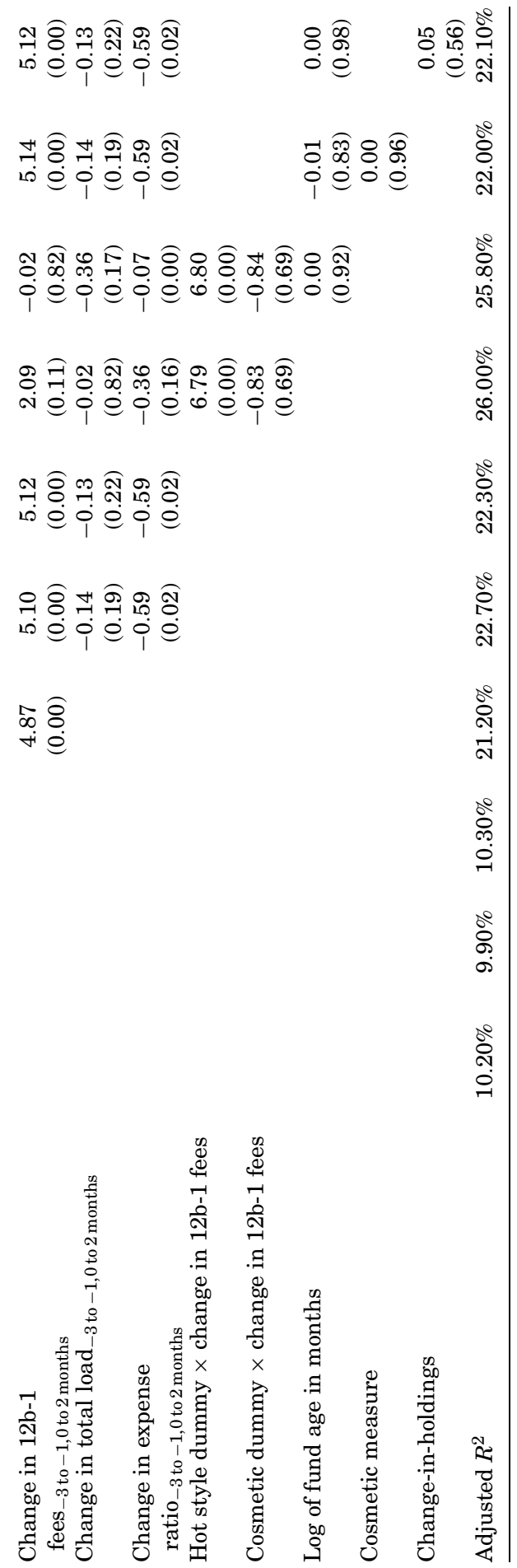


As a robustness test of our definitions of cosmetic/noncosmetic and changein-holdings, we therefore include a continuous cosmetic measure (the absolute value of the appropriate post-name-change HML or SMB loading) and a continuous change-in-holdings measure (the squared difference on the appropriate pre- and post-SMB or HML loadings). These two measures are alternative ways of capturing whether the name change is material. The continuous cosmetic measure assesses whether the fund's new name really reflects its holdings after the name change. The continuous change-in-holdings measure examines whether the fund materially changes its holdings from before to after the name change. We report these specifications in models 9 and 10. In neither model is the coefficient on the cosmetic or the distance measures significant. Thus, flows do not appear to be dependent on whether a fund's new name really reflects its holdings nor whether or not a fund changes its portfolio from before to after the name change.

Also, there is no difference between "to" style changes and "from" style changes. Performance prior to the name change does matter in determining post-event flows; the coefficients on the decile rank of a fund's Fama-French three-factor alpha is positive and significant in many of the model specifications. The size of the fund is also important; across all but one regression model, funds with lower TNA prior to the name change experience greater post-name-change flows. When we include fund age (specifications 8 to 10), it drives away the significance of TNA in model eight, but does not in models 9 and 10. However, fund age is insignificant. ${ }^{20}$ The change in $12 \mathrm{~b}-1$ marketing fees is positively and significantly related to the cross-section of fund flows in the post-name-change period, whereas the change in loads is not. Changes in total expenses are important; funds with higher total expense ratios have decreased flows after the name change. The fact that increased flows are associated with increased marketing expenditures is consistent with both Jain and Wu (2000) and Sirri and Tufano (1998).

\section{F. Are the Abnormal Flows Driven by Marketing?}

Fundamentally, name changes are changes in packaging that may or may not reflect changes in the fund. If these changes were deliberate, it seems reasonable to assume that funds would advertise as part of the same strategy that led to the name change. In other words, what good is a name change that nobody notes? Our results on the differences in fund flows between hot and cold style name-change funds might be driven by differences in advertising. Consistent with this, as noted in the last section, Table V shows positive and highly significant coefficients on $12 \mathrm{~b}-1$ fees for all regression parameterizations where noninteractive 12b-1 fees are included (models 4 through 6 , and 9 through 10 ).

\footnotetext{
${ }^{20}$ To control for potential multicollinearity between Age and TNA, we estimate model eight using Age but removing TNA (not reported in the tables). In this specification, the coefficient on Age is negative and significant $(p=0.01)$, suggesting that, controlling for other factors, younger funds experience greater flows after name changes.
} 
Sirri and Tufano (1998) discuss how advertising can be thought of as a means to reduce search costs for investors; in this light, an increase in inflows appears to be rational. The question we address in this section is whether the effect we document is a rational advertising effect or whether it is due at least in part to investor irrationality. If the abnormal fund flows to hot style name-change funds are entirely due to investors reacting rationally to advertising, we might expect to see three effects. First, changes in advertising should have the same effect on hot style and cold style name-change fund flows. Second, funds that do not change their advertising expenses should not experience an increase in abnormal flows. Third, hot style name-change funds that spend little or no money on advertising after the name change, should not experience an increase in abnormal fund flows.

We start by investigating whether changes to $12 \mathrm{~b}-1$ fees differentially affect hot and cold style name-change funds and cosmetic name changes. We add interactive dummies for hot/cold and cosmetic/noncosmetic funds; specifically, we add a hot dummy $\times 12 \mathrm{~b}-1$ fee variable (where the hot style dummy is equal to 1 if the name changes toward (away from) a particular style when the corresponding style premium is up (down), and 0 otherwise), and a cosmetic dummy $\times$ $12 \mathrm{~b}-1$ variable (where the cosmetic dummy is equal to 1 if the fund's new name accurately reflects its holdings, 0 otherwise). We report this specification in models seven and eight of Table V. Adding the interactive dummy terms drives away the significance of the noninteractive $12 \mathrm{~b}-1$ fee term and the expense ratio term, and reduces the significance of the Fama-French three-factor alpha. Controlling for fund age in model eight does not reduce the significance of the interactive hot dummy $\times 12 \mathrm{~b}-1$ fee term. The funds that appear to benefit most from advertising their new names are the hot name-change funds which have a positive and highly significant coefficient loading on the hot dummy $x$ 12b-1 fee variable. Note, however, that the abnormal flows to the hot style name-change funds are not driven entirely by marketing since the noninteracted dummy variable on hot style name changes is still statistically significant when the interaction term is included. The amount of advertising spent by cosmetic and noncosmetic funds does not result in significantly higher flows for either category of funds; the coefficient loading on the cosmetic dummy $x$ $12 \mathrm{~b}-1$ term is statistically insignificant.

We next directly investigate whether funds with no changes in advertising expenses experience increased post-name-change fund flows. We recompute the event study abnormal flows for Table IV, Panel A by only including those funds with no changes in 12b-1 fees from the 12 months prior to the 12 months after the name change. We find that 231 (65) name-change events occur without (with) changes in 12b-1 fees. Funds that change their names without changing their 12b-1 fees experience statistically significant CAFs of $18.69 \%$ in the year after the name change. Further, consistent with Table IV, Panel A, all the abnormal flows in the no-change-in-12b-1 funds are due to the hot namechange funds. The hot funds have abnormal flows of $25.89 \%$ in the year after the name change, significantly larger than cold fund flows of $1.55 \%$ over the same period. 
Third, we sort hot and cold name changes into the top half and bottom half of post-name-change $12 \mathrm{~b}-1$ fees. ${ }^{21}$ For both hot and cold funds, we expect that funds with high levels of advertising should experience increases in inflows. In contrast, for funds with low levels of advertising, we should expect no increase in flows for either hot or cold funds. An increase in fund flows for hot funds (if, in fact, investors target these funds because of the glamour style suggested in the fund's new name) suggests some degree of irrationality on the part of investors. ${ }^{22}$

Cold name-change funds experience abnormal flows of $0.41 \%(t$-statistic $=$ $0.11) 1$ year after the name change for the low $12 \mathrm{~b}-1$ fee funds and abnormal flows of $7.30 \%$ ( $t$-statistic $=1.66)$ for the high $12 \mathrm{~b}-1$ fee funds over the same period. Thus, cold name changes that take place without increases in advertising do not experience increased flows, and cold name changes accompanied by increases in advertising do experience an increase in flows, though this increase is only marginally statistically significant. The small increase in flows is not due to increases in post-name-change performance: The cold name-change funds with high $12 \mathrm{~b}-1$ fees have statistically insignificant three-factor alphas of $-0.06 \%$ in the year after the name change.

More interestingly, hot name-change funds in the bottom half of $12 \mathrm{~b}-1$ fees experience statistically significant increases in flows of $18.06 \%$ in the year after the name change, while paying out close to 0 in $12 \mathrm{~b}-1$ fees. This is quite dramatic, since these funds do not exhibit superior risk-adjusted performance in the year after the name change (their monthly three-factor alpha is $-0.13 \%$ $(t$-statistic $=-1.31))$ and spend almost no money on advertising. While hot name-change funds in the top half of $12 \mathrm{~b}-1$ fees experience statistically significant increases in flows of $37.19 \%$, similar to the low advertising hot-funds, these hot-style high advertising funds do not earn positive abnormal returns following the name change (their average monthly three-factor alpha is $-0.33 \%$ $(t$-statistic $=-4.12)$ ).

In both Jain and Wu (2000) and Sirri and Tufano (1998), increased marketing serves to highlight a fund's recent high performance. For example, Jain and Wu (2000) find that funds that advertise their strong performance earn an increase of approximately 5\% in the next year's fund flows. In contrast, the funds in our sample are quite average (and in some cases below average) in terms of preand post-name-change performance. Thus, investors appear to be deceived by the hot name-change funds' "new" glamour style and are deceived even more by the hot name-change funds that spend more on advertising.

${ }^{21}$ The 12b-1 fees and loads are clustered near 0 (see Table II, Panel C). Thus, the lower median of the $12 \mathrm{~b}-1$ fees is mostly 0 .

${ }^{22}$ We also examine the effects of the level of fund load after the name change. Sirri and Tufano (1998) discuss how both loads and 12b-1 fees may play important roles in reducing investors' search costs and thus promoting increased fund flows. Note that $12 \mathrm{~b}-1$ fees are sometimes used in combination with contingent-deferred sales charges to fully or partially reduce front-end loads (Haslem (2003)). When we sort on total loads, we find that higher load funds do have greater postname-change flows, but consistent with the regression results from Table $\mathrm{V}$, the difference in flows across low and high loads, for both cold and hot name changes, are not statistically significant. 
Our evidence on 12b-1 fees suggests two effects driving investor fund flows. First, investors might choose to invest in hot name-change funds simply due to the glamour style of the fund's new name. Second, investors may choose to invest in hot name-change funds because of marketing efforts by the funds, brokers, and investment advisors. The first effect involves an active search by investors to find a particular glamour style fund among the universe of all funds. This is consistent with our results for hot name-change, low 12b-1 fee funds. In contrast, the second effect arises from investors being unduly influenced by marketing efforts. In this case, investors are likely influenced by broker-initiated sales pressure highlighting the new glamour style of the fund. This latter effect is consistent with our results for hot name-change, high 12b-1 fee funds and with Elton, Gruber, and Busse (2004), who find that investors suboptimally invest in index funds with high loads and low returns (despite the existence of identical funds with low loads and higher returns).

The implication for fund managers desiring to increase flows is unambiguous: Make a hot style name change, do not worry about your fund's performance (no excess returns are required before or after the name change to achieve large increases in flows), and advertise your fund if you want the greatest possible increase in flows.

\section{G. Changes in Fund Characteristics from before to after the Name Change}

In Table VI, we report the average monthly change in pre-year to post-year characteristics of the name-change funds. There is a significant increase in the monthly fund flow from $0.01 \%$ to $1.65 \%$ across all funds. Again, this increase is mainly concentrated among hot style changes-after the name change, these funds earn an increased average monthly abnormal fund flow of $2.28 \%$ in the year after the name change. In contrast, cold style name changes earn a statistically insignificant average monthly abnormal flow of $0.33 \%$ in the year after the name change. The loads, expenses, and 12b-1 fees do not change significantly over the period.

After the name change, the funds do not perform better relative to their pre-name-change performance. Across all fund categories, the three-factor alphas are on average negative and not statistically different across the pre- and post-name-change periods. For the hot fund name changes, the before and after three-factor alphas are significantly negative, with a before-alpha of -0.11 $(t$-statistic $=-1.92)$ and an after-alpha of $-0.23(t$-statistic $=-3.63)$. In terms of raw returns, there is evidence that they actually perform worse. The average name-change fund earns monthly returns of $1.34 \%$ in the year before the name change. This drops to $0.43 \%$ in the year after. Hot style name-change funds experience a drop from $1.42 \%$ to $0.33 \%$ in the year before and after the name change, respectively. Cold style funds experience a smaller drop from $1.28 \%$ to $0.51 \%$ over these two periods. This has an effect on the TNA figures reported in Table VI for the two types of funds. While hot style name-change funds earn significantly higher fund inflows than cold style name-change funds, the lower raw returns they earn on average from the year before to the year 


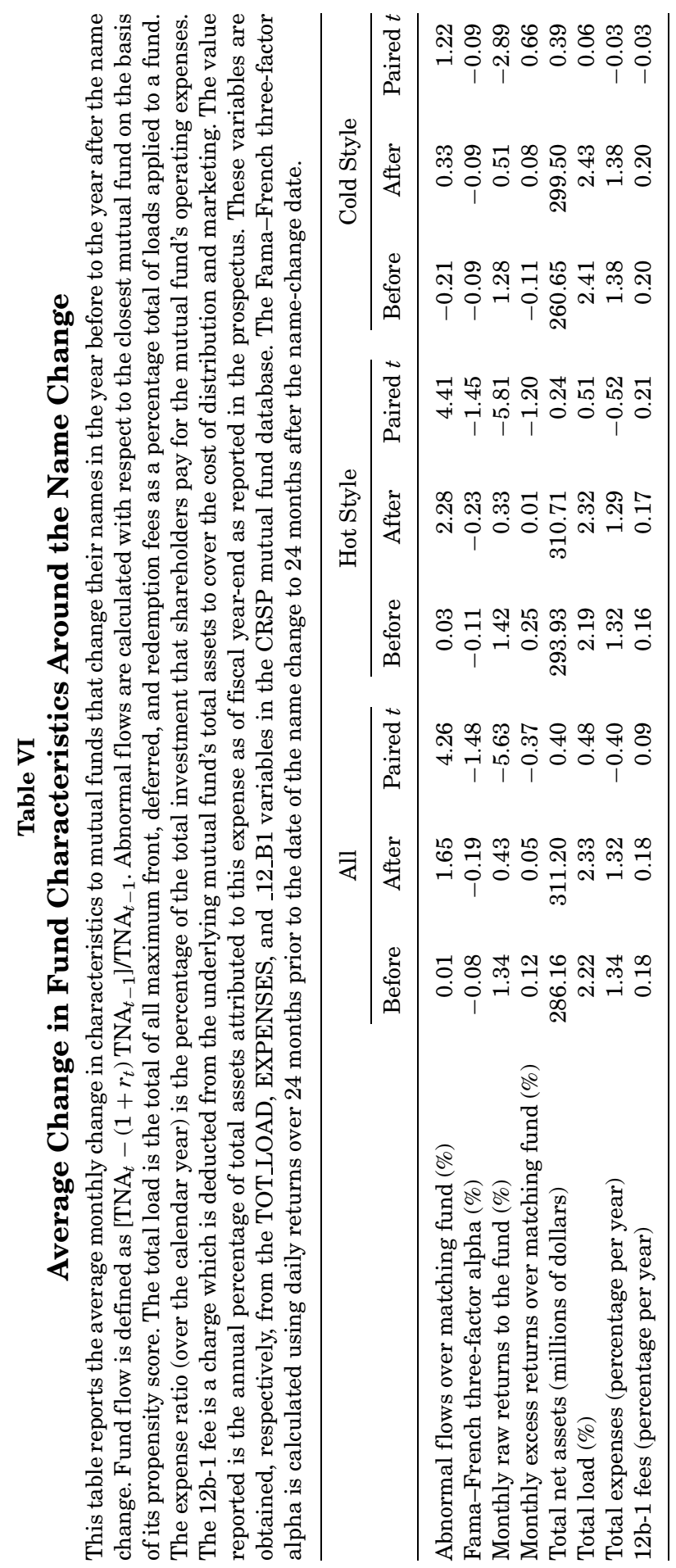


after the name change, relative to the cold style funds, implies that the TNA in the hot style name-change funds increases on average from $\$ 293.93$ million to $\$ 310.70$ million-an increase of $5.71 \%$. In contrast, TNA for the cold style namechange funds increase from $\$ 260.65$ million to $\$ 299.50$ million, an increase of $14.91 \% .^{23}$

\section{Conclusions}

We identify a sample of equity mutual funds that make a style name change over an 8-year period. Compared to other funds in the universe of equity mutual funds, the name-change funds experience a significantly negative fund flow over the 6 months before the name change, they earn lower excess returns (as measured by Fama-French three-factor alphas), they are older, and they charge lower marketing $12 \mathrm{~b}-1$ fees.

When they do change their names, the funds earn significantly positive abnormal fund flows. Flows in excess of those earned by a matching fund are on the order of $20 \%$ in the 1 year after the name-change month. The increase in fund flow is almost entirely concentrated, however, on funds that make a hot style name change. These funds earn CAFs of $27.63 \%$ in the year after the name-change month, $23.65 \%$ more than funds making cold style name changes. There is no difference in abnormal flows across cosmetic and noncosmetic namechange types.

Advertising, performance, and TNA are significant in determining abnormal fund flows to these funds-larger funds attract less flows, while funds that perform better and funds that advertise more attract more flows. Even after controlling for these factors, however, hot style name changes are significantly positively related to the magnitude of the abnormal flows.

To summarize our evidence, funds that have not spent much on marketing fees and that have experienced a significant drop in their fund inflows change their names to realize an increase in flows. Part of this increase is due to the increased advertising associated with the name change. However, there is no relation between the degree to which the fund actually changes its portfolio holdings and the increase in fund flows. Instead, the fund flow seems to be driven almost entirely by changes into hot styles.

Sirri and Tufano (1998) find that consumers tend to flock to funds with recent superior performance, despite the evidence in Carhart (1997) that mutual fund managers do not exhibit short-term persistence once rewards to following mechanical strategies such as value and momentum investing are controlled for.

\footnotetext{
${ }^{23}$ The larger percentage increase in TNA for the cold style funds relative to the hot style funds is due to a smaller decrease in pre-to-post raw returns for the cold funds and to a large outlier fund in the cold style sample. When we remove the largest cold style fund (TNA $=\$ 8.47$ billion) and hot style fund (TNA $=\$ 6.98$ billion) based on TNA prior to the name change, the average TNA value before and after the name change for the cold style funds is $\$ 215$ million and $\$ 223$ million, respectively. The hot style average TNA value before and after the name change is $\$ 255$ million and $\$ 283$ million, respectively. The before and after flows for both hot and cold style funds are virtually unchanged by removing these two funds.
} 
Building on these results, our findings suggest that not only do fund investors behave less than optimally in ignoring Carhart (1997), but that a simple and appropriately timed name change can easily trick fund consumers into believing that a fund belongs to a current hot style. On average, the investors in these hot name-change funds lose money after the name change on a raw return basis, and are no better off on a three-factor model basis. Thus, given that the average switching costs are relatively high (total loads, expenses, and fees are about $3.75 \%$ ), investing in these name-change funds appears to be suboptimal behavior on the part of mutual fund investors.

It is interesting to contrast our results with Berk and Green (2004), who develop a rational model of active mutual fund management to predict the relation between flows and subsequent fund returns. They show that a relation among high past performance, subsequent increased investor flows, and subsequent insignificant excess returns is not inconsistent with investor rationality. In their model, some managers may have superior skills, but because of the competitive market for capital, combined with decreasing returns to scale in active management, many managers are not able to parlay their skills into continued abnormal performance. In contrast, we find large increases in flows in a setting with no pre-name-change excess performance for either the hot or cold style funds, respectively, suggesting that our documented name-change abnormal flows are not explained by the Berk and Green (2004) model. Whether the reader believes that the documented fund flows in this paper provide evidence of irrational investor behavior, or just informationally constrained investors being taken advantage of by smart managers, our results nonetheless suggest policy implications related to better fund disclosure requirements.

Data on actual portfolio holdings by mutual funds are hard to obtain. As the Wall Street Journal (see McDonald (2002)) reports,

So far this year the Investment Company Institute (ICI), the fund industry's largest trade group, has asked corporate managers to: speed up their earnings reporting; be more open about corporate insider trading; and seek shareholder approval for stock option plans, among other corporate governance initiatives. In a puzzling twist, however, the ICI maintains its long-held stance that funds shouldn't have to disclose their full portfolio holdings more than twice each year. Among its arguments: few of the more than 93 million individual U.S. fund investors have asked for more frequent and robust disclosure of where their more than $\$ 5$ trillion in assets are stashed. It's curious that the fund industry remains immune to the disclosure rage that has thus far focused on Wall Street, accountants and publicly traded companies. Right now, federal rules require funds to provide full portfolio disclosure in semiannual shareholder reports, though data are often months old when presented to fund holders. In a fast-moving market, this seems a bit thin.

Similarly, the current Securities and Exchange Commission (SEC) rules on fund names mandate that a fund have at least $80 \%$ of their assets invested in whatever securities their names suggest (O'Brian (2001)). However, there 
appears to be significant leeway in the application of this rule. For example, fund names which include the terms "small cap," "midcap," and "large cap" must abide by the rule if an individual fund defines what those capitalization categories are in its prospectus. Making matters worse, there are no restrictions on using "value" and "growth" in a fund's name. It is not surprising therefore that investors have little else to go on but the name when making their fund allocation decisions. $^{24}$

However, there is some reason to believe that the behavior we document is at least partly driven by investor irrationality. All the flows appear to be concentrated among hot name changes. Further, these abnormal fund flows are not concentrated in the period immediately after the name change; rather, they show a steady increase over the year after the name change. In addition, there is no post-event negative drift in flows even up to 1 year after the name change either for cosmetic or noncosmetic name changes. It is difficult to believe that investors obtain no information about fund holdings over this stretch of time.

In this sense, our results add support to a growing body of literature documenting irrational investor behavior. Elton et al. (2004) document that investors do not select S\&P 500 index funds based entirely on rational factors such as expected returns. Instead, they find that a large amount of new fund flow goes into the poorest performing funds. In addition, similar to the dotcom mania (Cooper et al. (2001), Cooper et al. (2004)), this paper shows that mutual fund managers may be timing corporate actions to profit from investor irrationality. Name changes that correspond to hot periods of investment styles appear to take advantage of investors who disregard the underlying performance of the fund and instead invest in funds simply on aesthetic effects. This is broadly consistent with Capon, Fitzsimmons, and Prince (1996) who document that most investors have little knowledge about the products that they are buying.

${ }^{24}$ Barnett (2004) provides details on the SEC rules governing mutual fund names. 


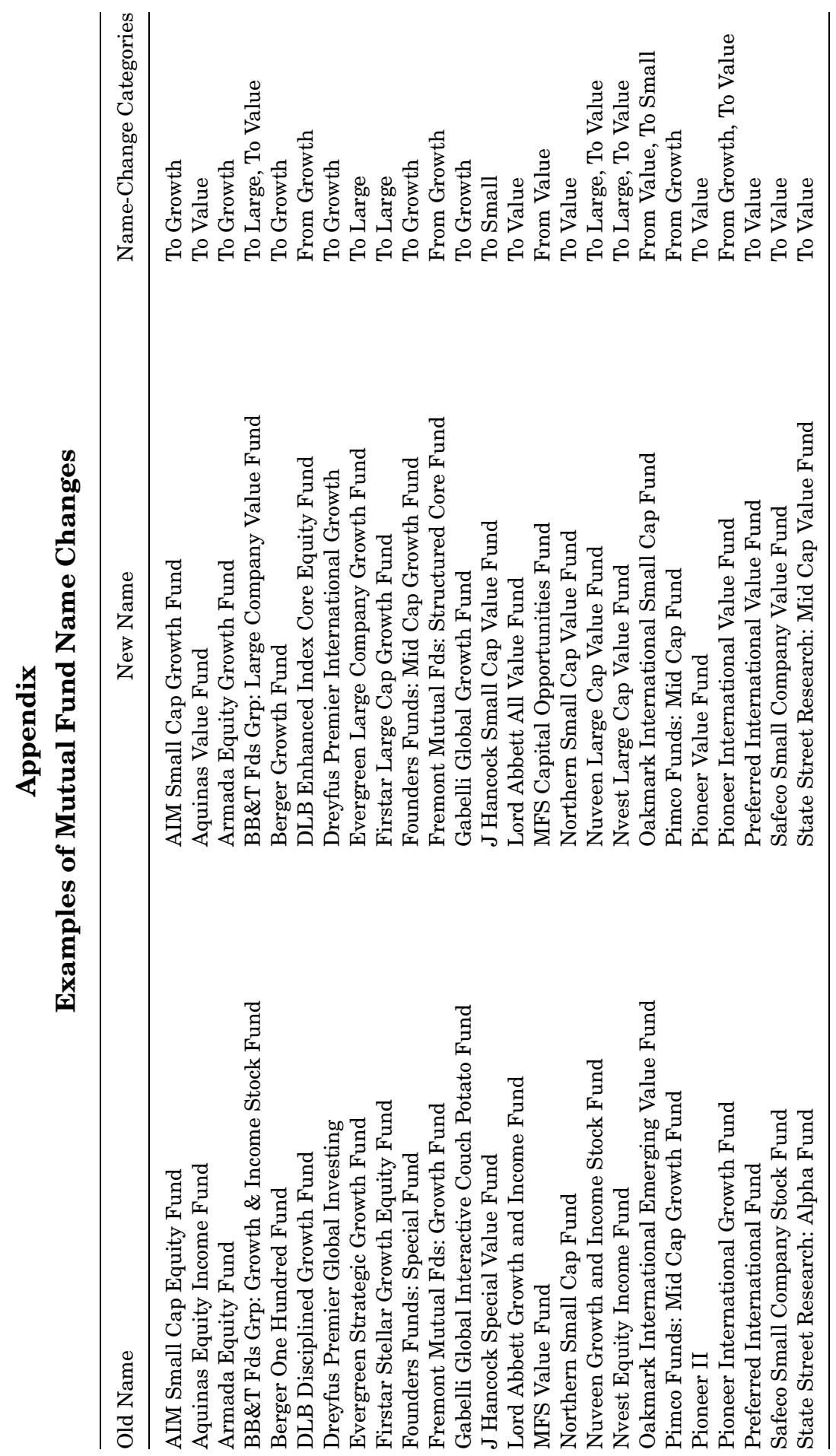




\section{REFERENCES}

Baker, Malcolm, and Jeffrey Wurgler, 2000, The equity share in new issues and aggregate stock returns, Journal of Finance 55, 2219-2257.

Baker, Malcolm, and Jeffrey Wurgler, 2002, Market timing and capital structure, Journal of Finance 57, 1-32.

Baker, Malcolm, and Jeffrey Wurgler, 2004, A catering theory of dividends, Journal of Finance 59, 1125-1165.

Barberis, Nicholas, and Andrei Shleifer, 2003, Style investing, Journal of Financial Economics 68, 161-199.

Barnett, Larry D., 2004, The regulation of mutual fund names and the societal role of trust, Working paper, Widener University.

Berk, Jonathan B., and Richard C. Green, 2004, Mutual fund flows and performance in rational markets, Journal of Political Economy 112, 1269-1295.

Capon, Noel, Gavin Fitzsimmons, and Roger Prince, 1996, An individual level analysis of the mutual fund investment decision, Journal of Financial Services Research 10, 59-82.

Carhart, Mark, 1997, On persistence in mutual fund performance, Journal of Finance 52, 5782.

Carhart, Mark, Jennifer N. Carpenter, Anthony W. Lynch, and David K. Musto, 2002, Mutual fund survivorship, Review of Financial Studies 15, 1439-1463.

Chen, Joseph, Harrison Hong, Ming Huang, and Jeffrey D. Kubik, 2004, Does fund size erode mutual fund performance? The role of liquidity and organization, American Economic Review 94, 1276-1302.

Chevalier, Judith A., and Glenn D. Ellison, 1997, Risk taking by mutual funds as a response to incentives, Journal of Political Economy 105, 1167-1200.

Cooper, Michael J., Orlin Dimitrov, and P. Raghavendra Rau, 2001, A rose.com by any other name, Journal of Finance 56, 2371-2388.

Cooper, Michael J., Ajay Khorana, Igor Osobov, Ajay Patel, and P. Raghavendra Rau, 2005, Managerial actions in response to a market downturn: Corporate name changes during the dot.com decline, Journal of Corporate Finance 11, 319-335.

Elton, Edwin J., Martin J. Gruber, and Jeffrey A. Busse, 2004, Are investors rational? Choices among index funds, Journal of Finance 59, 261-288.

Fama, Eugene F., and Kenneth R. French, 1993, Common risk factors in the returns on stocks and bonds, Journal of Financial Economics 33, 3-56.

Fama, Eugene F., and Kenneth R. French, 1996, Multifactor explanations of asset pricing anomalies, Journal of Finance 51, 55-84.

Goetzmann, William, Massimo Massa, and K. Geert Rouwenhorst, 2002, Behavioral factors in mutual fund flows, Working paper, Yale School of Management.

Goetzmann, William N., Zoran Ivković, and K. Geert Rouwenhorst, 2001, Day trading international mutual funds: Evidence and policy solutions, Journal of Financial and Quantitative Analysis 36, 287-309.

Goetzmann, William N., and Nadav Peles, 1997, Cognitive dissonance and mutual fund investors, Journal of Financial Research 20, 145-158.

Gruber, Martin, 1996, Another puzzle: The growth in actively managed funds, Journal of Finance $51,783-810$.

Haslem, John A., 2003, Mutual Funds: Risk and Performance Analysis for Decision Making (Blackwell Publishers Ltd., Malden, MA).

Hillion, Pierre, and Theo Vermaelen, 2004, Death spiral convertibles, Journal of Financial Economics 71, 381-415.

Hirshleifer, David A., 2001, Investor psychology and asset pricing, Journal of Finance 56, 15331597.

Huberman, Gur, and Tomer Regev, 2001, Contagious speculation and a cure for cancer: A nonevent that made stock prices soar, Journal of Finance 56, 387-396.

Ippolito, Richard A., 1992, Consumer reaction to measures of poor quality: Evidence from the mutual fund industry, Journal of Law and Economics 35, 45-70. 
Jain, Prem C., and Joanna Shuang Wu, 2000, Truth in mutual fund advertising: Evidence on future performance and fund flows, Journal of Finance 55, 937-958.

Jayaraman, Narayanan, Ajay Khorana, and Edward F. Nelling, 2002, An analysis of the determinants and shareholder wealth effects of mutual fund mergers, Journal of Finance 57, 15211551.

Lakonishok, Josef, Andrei Shleifer, and Robert W. Vishny, 1992, The impact of institutional trading on stock prices, Journal of Financial Economics 32, 23-43.

Lynch, Anthony W., and David Musto, 2003, How investors interpret past fund returns, Journal of Finance 58, 2033-2058.

McDonald, Ian, 2002, Tell me more: Finger-pointing funds should look in mirror, Wall Street Journal, August 28, C4.

O'Brian, Bridget, 2001, What's in a name? To the SEC, $80 \%$ of a fund, Wall Street Journal, July 9, C1.

Rashes, Michael S., 2001, Massively confused investors making conspicuously ignorant choices (MCI-MCIC), Journal of Finance 56, 1911-1927.

Shleifer, Andrei, and Robert W. Vishny, 2003, Stock market driven acquisitions, Journal of Financial Economics 70, 295-311.

Sirri, Erik R., and Peter Tufano, 1998, Costly search and mutual fund flows, Journal of Finance 53, 1589-1622.

Smith, Keith V., 1978, Is fund growth related to fund performance? Journal of Portfolio Management, Spring, 49-54.

Spitz, A. E., 1970, Mutual fund performance and cash inflow, Applied Economics 2, 141-145.

Villalonga, Belén, 2004, Does diversification cause the diversification discount? Financial Management 33, 5-27.

Warther, Vincent A., 1995, Aggregate mutual fund flows and security returns, Journal of Financial Economics 39, 209-235.

Wine, Elizabeth, and Sullivan, Aline, 2001, Growth makes way for value in mutual fund name changes, Financial Times, March 21, 40. 